\title{
Summer Monsoon Rainfalls in China
}

\author{
By Ding Yihui \\ Chinese Academy of Meteorological Sciences, State Meteorological Administration, Beijing \\ (Manuscript received 17 June 1971, in revised form 3 December, 1971)
}

\begin{abstract}
This paper presents a comprehensive review of summer monsoon rainfalls in China, with a special emphasis on the effects of the monsoonal airflow and large-scale terrain features in East Asia. The following aspects have been addressed: climatology of summer monsoon rainfalls in China, regional patterns of the summer monsoon rainfall, including the pre-summer rainfalls over South China, the Meiyu season and the rainy season in North China, the low-level jet associated with summer monsoon rainfalls, meso-scale features of precipitating systems during the summer monsoon season, atmospheric heat sources and their effect on the change in the general circulation in East Asia, and numerical experiments and operational prediction of the summer monsoon precipitation in China.
\end{abstract}

\section{Introduction}

China is greatly affected by summer monsoons and their associated rainfalls. A notable example for severity and duration of rainfalls is Meiyu (Plum Rains) occurring over the valley of the Yangtze River. Almost every year much damage is brought about in China by flash floods or persistent floods caused by excessively heavy rains during the summer monsoon season (Tao et al., 1980). In some years, the regional loss of property and lives reaches disaster proportions, exemplified by the intensive and devastating flood of the Huaihe River (in the central part of China) early in August, 1975 (Ding et al., 1978). On the other hand, great interannual vagaries of the monsoon activity has often caused extensive and prolonged droughts that may exert a vast impact on the socio-and economic development of China, especially agriculture and water resources.

For years, much emphasis has been placed on the research dealing with monsoon rainfalls in China, with the aim to gain a better understanding of their formation and then to improve their prediction. A half century ago, Zhu (1934) for the first time systematically discussed the problem of the monsoon and the associated monsoon rainfall, in his paper entitled "Monsoons in Southeast Asia and rainfall amount in China". For the last half century, great progress in the study of monsoon rainfalls has been made. In 50's, the research in this regard was focused on large-scale circulation conditions and rainbearing synoptic systems (Xie, 1956). During the past two decades much effort has been made to understand better the causes and physical conditions

(C)1992, Meteorological Society of Japan (dynamical and thermal) leading to the occurrence of monsoon rainfalls, in particular the associated heavy rainfalls and severe convective weather (Xie, 1984; Ding et al., 1980). Emphasis has been also placed on the study of small-and meso-scale weather systems and interaction between the meso-scale systems and the large-scale environment. In addition to these efforts, many meteorological services at the provincial level and other interested institutions and organisations cooperated in putting into operation several field experiments. One of these experiment was directed towards observing and studying the pre-summer rainfall in South China (Experiment on Presummer Heavy Rainfall over South China, 19771980). The other was designed to examine the severe convective weather, especially hailstorms and destructive wind events associated with squall lines in Hunan province. During the period 1980-1983 the East China Meso-scale Weather Experiments were undertaken, with the main objective to investigate the structure and maintenance mechanism of the meso-scale disturbances within the Meiyu front. Twenty six radiosonde stations were set up in the area $30-35^{\circ} \mathrm{N}, 115-122^{\circ} \mathrm{E}$, with an average interval of $90 \mathrm{~km}$ and hourly precipitation data from 1320 raingauge stations were recorded. In addition, nine rain-detecting weather radars were used to monitor the continued evolution of meso-scale systems or events in the entire experiment area. A special intensive observation period was conducted during 24-27 June, 1981, to capture the feature of mesosystems embedded in the Meiyu front. The major findings have been summarized in the monograph "A Study on the Heavy Rainfall of Meiyu Front over the Valley of the Yangtze River" (Zhang, 1990). Re- 
cently, the National Research Program of the Monitoring System and the Very-Short Range Prediction of the Disastrous Weather in China has been completed (Ding and Zhou, 1988). This is an operational and research program, basically similar to Nationl Storm Program in the U.S.A.

Four experimental areas in China have been selected with high priorities and developed the monitoring and very-short range forecasting system of disastrous weather: Beijing-Tianjin-Hebei (Beijing), the Yangtze River delta area (Shanghai), the Pearl River delta area (Guangzhou) and the Sanxia district on the Yangtze River (Wuhan).

Although much research has already been done in recent years based upon the data sets acquired in these field experiments, the usefulness of these valuable data does not seem to be exhausted. At the present time the state of the art of prediction of monsoon precipitation in China is not as good as the prediction of large-scale synoptic situations, although some significant progress and improvements have been made, including the operational use of regional precipitation numerical prediction (Guo et al., 1990; Zou, 1989). Many failures may be attributed to the short time interval between the occurrence of rainfalls and the availability of the necessary data in preparation of a forecast for 12-36 hours in advance. The monsoon precipitation in East Asia is a rather complex phenomenon. A great deal more research should be devoted to this problem before its useful and successful prediction can be made.

\section{Climatological aspect of summer monsoon rainfall}

China, as part of East Asia, is greatly influenced by the monsoon circulation from South Asia or the West Pacific Ocean every spring and summer. The active monsoon may reach the Northeast, North and Northwest portions of China during mid-summer. With the circulation prevailing during monsoon régimes, coupled with the effects of the complicated terrain features, monsoon rainfalls can frequently occur in China in the rainy season (Ding and Reiter, 1982; Tao and Ding, 1981).

The rainy season in China generally begins with the onset of the summer monsoon and ends with its withdrawal. Rainfall intensity and its variation are closely related to the fluctuations of the summer monsoon. When the summer monsoon advances northward, its leading zone, the monsoon rain belt, correspondingly moves from a low-latitude to midand high latitudes. In this process, as does the monsoonal airflow, the monsoon rain belt undergoes three standing stages and two stages of abrupt northward jump. Based on the time-latitude crosssection of 10-day rainfall amount for eastern China (Fig. 1) (Lau et al., 1988), the most conspicuous feature is the monsoon onset between $25^{\circ}$ and $30^{\circ} \mathrm{N}$ as

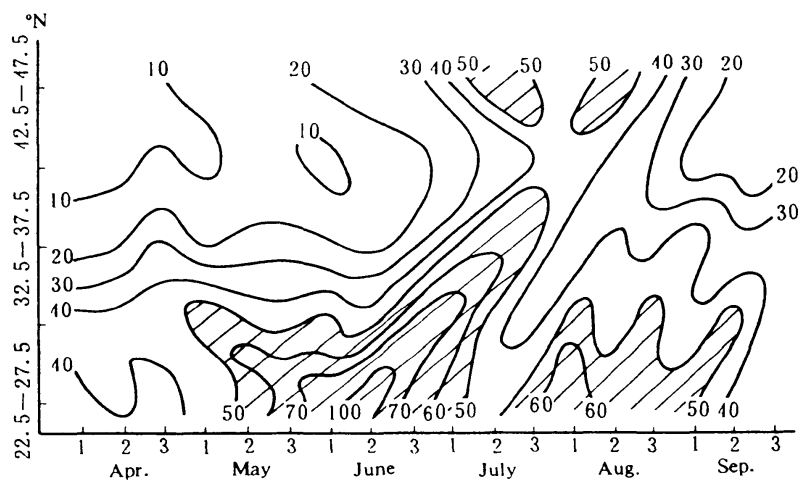

Fig. 1. Time-latitude section of 10-day mean rainfall over eastern China $\left(100-115^{\circ} \mathrm{E}\right)$, Units in $\mathrm{mm}(10 \text { days })^{-1}$. Regions of heavy rain $(>50 \mathrm{~mm})$ are shaded. The heavy dashed lines indicate northward propagation of the rainbands (Lau, Yang and Shen, 1988).

indicated by the steep rise in precipitation starting from the first 10-day period of May (other 10-day periods are similarly defined). This characteristic feature has been also studied by Japanese investigators (Yoshino, 1965; Matsumoto, 1989).

The first standing stage of the major rain belt generally continues into the first 10-days of June, and afterwards it rapidly shifts to the valley of the Yangtze River. This second stationary phase starts the rainy season there that is so-called Meiyu (Plum Rains) in central China. The time span of the Meiyu season on the average lasts for one month (10th June-10th July). From mid-July, the rain belt rapidly moves over North China and in August farther over Northeast China, the northernmost position of summer monsoon rainfalls. This standing stage of the rain belt causes the rainy season in the northern China that generally lasts for one month. In the last part of August the rainy season of North China comes to end, with the major rain belt retreating southward. At the end of August it crosses the Yellow River and early in September it moves back to South China again. At this time, most of eastern part of China is dominated by a dry spell. Note that from mid-July the second rainy season predominates over South China, with a gap of a time period of one month between the pre-summer rainy season and this rainy season, that is mainly caused by typhoons, ITCZ and other tropical disturbances. Around the beginning of October, the rainy season over eastern China more or less ends and rapidly makes way for the winter monsoon. Guo and Wang (1981) also analysed climatological patterns of summer rainfalls by use of a longer record of precipitation in China (1950-1979). Similarly, they pointed out that the summer monsoon rain belt assumed three relative stable periods, with the first pe- 

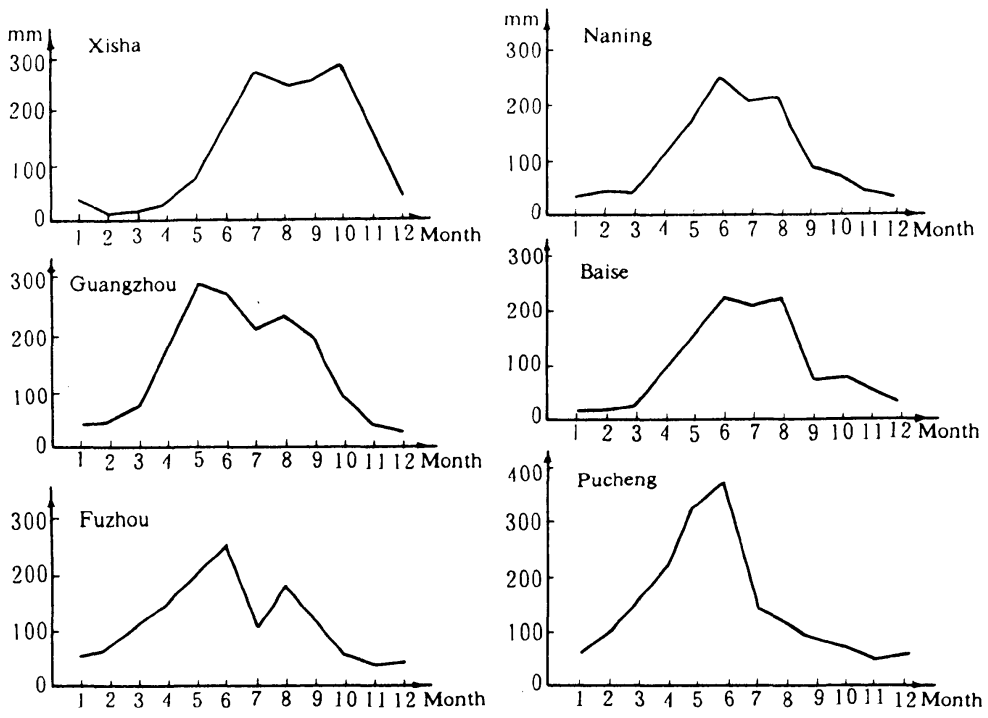

Fig. 2. The long-term mean (1960-1979) annual range of rainfall amount at several selected stations for South China; Xisha $\left(17^{\circ} \mathrm{N}, 113^{\circ} \mathrm{E}\right)$, Cuangzhou $\left(23^{\circ} \mathrm{N}, 113^{\circ} \mathrm{E}\right)$, Fuzhou $\left(26^{\circ} \mathrm{N}, 119^{\circ} \mathrm{E}\right)$, Nanning $\left(23^{\circ} \mathrm{N}\right.$, $\left.108^{\circ} \mathrm{E}\right)$, Baise $\left(24^{\circ} \mathrm{N}, 107^{\circ} \mathrm{E}\right)$, Pucheng $\left(28^{\circ} \mathrm{N}, 119^{\circ} \mathrm{E}\right)$. Unit: mm. (Huang, 1986).

riod (the pre-summer rainy season in South China) having the longest persistence, the third period (the rainy season in North China) the second longest persistence and the second period (the Meiyu season) the shortest.

To the south of $30^{\circ} \mathrm{N}$, the monsoon rainfall seems to be modulated by a 30-50 day period oscillation while low-frequency oscillations of the period on the order of 20 days appear to dominate the rainfall variation between 25 and $40^{\circ} \mathrm{N}$ for the remaining part of the season from the later part of July to the end of September. These 20-day fluctuations appear to originate around $25^{\circ} \mathrm{N}$ and propagate northward to $40^{\circ} \mathrm{N}$. Shi and Chao (1983) documented the presence of this low-frequency oscillation based on a powerspectrum analysis of the wind field and some thermodynamic quantities at Beijing $\left(40^{\circ} \mathrm{N}\right)$. This indicates that this characteristic oscillation of the monsoon régime may propagate up to very high latitude.

The 40-day rainfall fluctuations over East Asia are most likely related to the global 40-50 day oscillation found by Madden and Julian (1972). Lau et al. (1988) suggest that abrupt changes or "sudden jumps" by the major rainfall belt are related to the phase-locking between an intraseasonal oscillation such as the 40-day mode and 20-day mode and the seasonal cycle. This unique process leads to wave-like progress from south to north of monsoon rainfall over East Asia from April to September, as described above.

The monsoon rainfall for western China including Tibet is a much simpler picture, compared to the east. The rainfall season is quite well defined around $30^{\circ} \mathrm{N}$. The heavy monsoon rain comes late in the season around 20-31st, July and lasts only briefly for a little longer than a month without a break. There is a persistent minimum in rainfall around $40^{\circ} \mathrm{N}$. Farther north, rainfall appears to be sporadic and ill-organised. Based on the study by Lin (1987), however, the patterns of rainfall in western China are more complex. The rainfall events and spells caused by local conditions are often superposed on the summer monsoon rainfall patterns, so that the onset and ending dates of rainy seasons in this region appear to be less regular.

The rainfall in the East Asian monsoon region assumes a considerable interannual variability. In most of the China region, the mean interannual variability of rainfalls ranges from $10 \%$ to $30 \%$ (Tao et $a l ., 1980)$. However, there is a marked regional difference. For South China and the Tibetan Plateau, the interannual variability is low, generally in the range of 10-15\%, while for North China and Northeast China, the interannual variability rises to $15-30$ $\%$. The greatest interannual variability of rainfalls in China is observed in arid and semi-arid zones, generally with $30-50 \%$, even as high as $50-60 \%$ at some stations in Northwest China. This highly unsteady annual rainfall may greatly affect the agricultural production, due to high vulnerability to droughts and floods.

\section{Regional patterns of the summer monsoon rainfall}

\section{(1) Pre-summer rainfalls over South China}

During April to June, the rain belt swings over South China, thus causing the pre-summer rainy season in this region. Figure 2 is the annual range of the long-term mean (1960-1979) rainfall amount at several selected stations of South China (Huang, 


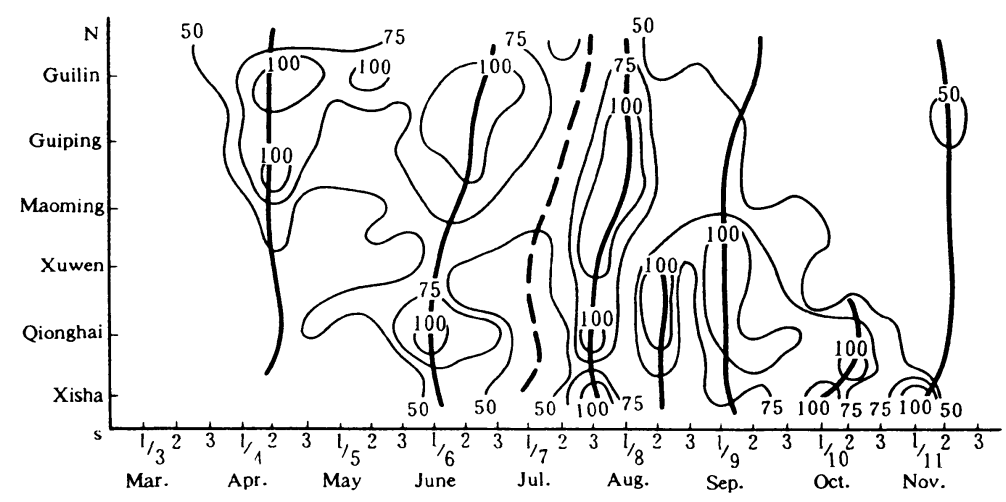

Fig. 3. Temporal cross-section of the 10-day mean of precipitation amount over South China (Xisha: $17^{\circ} \mathrm{N}$, Qionghai: $20^{\circ} \mathrm{N}$, Maoming: $22^{\circ} \mathrm{N}$, Guilin: $25^{\circ} \mathrm{N}$ ) along $110^{\circ} \mathrm{E}$ for March-November averaged for 1976 1980. Unit: $\mathrm{mm}$ (10 days) ${ }^{-1}$. (Huang, 1986).

1986). It can be seen that the distribution of rainfall amount for most of South China assumes a marked double-peak pattern, with the peaks observed in May to June (the pre-summer rainy season) and August (the typhoon rainy season caused by typhoons and other tropical weather systems), respectively, and even with the former peak of rainfall amount being greater than the latter peak. Thus, the presummer rainy season is the major rainy season for South China.

The fluctuating feature of spring and summer precipitation over South China shows up in short- and medium term fluctuations. Figure 3 is indicative of the periodic variation of precipitaion for MarchNovember of $1976-1980$, with the period of $40-60$ days dominating. Note that the pre-summer rainy season really is a major part of this medium-term fluctuation of precipitation, lasting from the early part of May to the middle part of June. The analysis of the power spectrum for the precipitation at Guangzhou further shows that there is also 12-day fluctuation besides a 40-60 day fluctuation. The above two fluctuations of precipitation over South China clearly reflect the corresponding oscillations of the Indian and East Asian summer monsoon with the same periods. When the easterly wind weakens, the precipitation significantly increases and the peak of precipitation occurs shortly before the transition from the easterly wind to a westerly wind.

The pre-summer rainy season over South China occurs under special large-scale synoptic conditions that are characterized by the following events (Huang, 1986): the first northward jump of the subtropical high over the West-Pacific, the onset of the East Asian summer monsoon over the South China Sea, and gradual weakening of cold air activities in East Asia, but still with frequent intrusions into the region of South China accompanied by the process of cold fronts. So, this seasonal rain belt is caused by the combined effect of the synaptic systems in westerlies and the summer monsoon flow at the location of South China.

As the summer monsoon sets in, the crossequatorial airflow, which is a low-level southerly aircurrent originating in the Australian region, may flow northward up to South China, causing the air temperature and humidity at low-level to increase, especially in the layer from 500-1000 m. Much evidence has been provided to indicate that the peak stage of the pre-summer rainy season over South China starts with the establishment of the crossequatorial airflow over the coastal area of South China. To a certain extent, the short-term variability of precipitation of the pre-summer rainy season is modulated by the activity of monsoons in East Asia, especially the monsoon surges. Based on the recent statistics of monsoon surges for April-August made by Rong et al. (1987), 37 of 47 studied cases (79\%) were accompanied by the precipitation episodes in South China.

The three major rain-bearing synoptic systems for the pre-summer rains have been identified (Huang, 1986). The first one is the surface baroclinic zone (South China cold front and stationary front), synoptic-scale convergence zones (monsoon trough, frontal low-pressure trough), and warm and moist zones. The second type of synaptic-scale rainbearing system includes a low-level jet, low vortices and shear-lines in wind field and convergent lines in the boundary layer. These synoptic-scale systems may cause heavy rainfalls mainly as triggering mechanisms and suppliers of moisture. The third type is related to the middle and upperlevel synoptic systems which may be identified as troughs on the southern branch in westerlies or troughs in mid-latitude westerlies, mid-tropospheric cyclones, the subtropical high ridge, the subtropical jet and upper-level divergence flow field. A significant episode of pre-summer heavy rainfall requires the right superposition and horizontal juxtaposition of these systems or part thereof. The characteristic situation favorable for the occurrence of pre-summer 
heavy rains has been studied. At the upper-level, the subtropical jet generally intensifies as the cold air comes down and has a more southern position. There is a divergent flow ahead of the ridge. At the middle level the synoptic situation is characterized by a trough in the westerlies. The precipitation in warm sector is most'significant for the pre-summer rainy season. The physical conditions for this type of heavy rainfall have been estimated based on the data obtained during the Experiment on Presummer Heavy Rainfall over South China (1977-1978). The salient feature is the presence of a deep moist layer, with the near-saturation layer extending upward to $500 \mathrm{hPa}$, or even higher to $200 \mathrm{hPa}$. The strong baroclinic layer is mainly observed below 850 $\mathrm{hPa}$, indicating that the activity of cold air associated with heavy rainfalls is concentrated in the boundary layer. The atmospheric stratification in the warm sector is usually unstable below $600 \mathrm{hPa}$.

There is significant convergence below $850 \mathrm{hPa}$, with the maximum found at $950 \mathrm{hPa}$. In the middle and upper troposphere, the divergence and anticyclonic vorticity often lies over regions of heavy rainfall.

The activity of the low-level jet is closely related to the heavy rainfalls in South China. Many events of pre-summer heavy rainfalls were accompanied by the activity of low-level jets. This problem will be discussed in more detail in Section 4.

\section{(2) The Meiyu (Plum Rains) over the Yangtze River valley}

In the Yangtze River valley, the rainy period from mid-June to mid-July is called the Meiyu or Plum Rains. This rainy season is characterized by abundant precipitation, high relative humidity, cloudy or overcast, short daily duration of sunshine, weak surface wind and frequent occurrence of heavy rainfalls. The precipitation is mostly of a continuous and stable nature, but sometimes with thunderstorms and showers. During the Meiyu season, the Yangtze River valley is vulnerable to flooding and droughts, due to the relative concentration and severity of the rainfall amount. Based on the statistics of MaySeptember of 1966-1975, about $40 \%$ of heavy rainfalls occur during one month from mid-June to midJuly which just corresponds to the Meiyu season.

The onset of the Meiyu period is closely related to the prominent change in the circulation features in the monsoon regions that are characterized by the following major events (Yeh et al., 1958; Yoshino, 1971): the onset of the Indian summer monsoon, the abrupt northward jump of the westerly jet from northern India or south of the Tibetan Plateau to the northern part of the plateau, the northward shift of the axis of the anticyclone at $100 \mathrm{hPa}$ to $30^{\circ} \mathrm{N}$, and the northward advance of the subtropical high over the West Pacific from $20^{\circ} \mathrm{N}$ to $25^{\circ} \mathrm{N}$. A recent

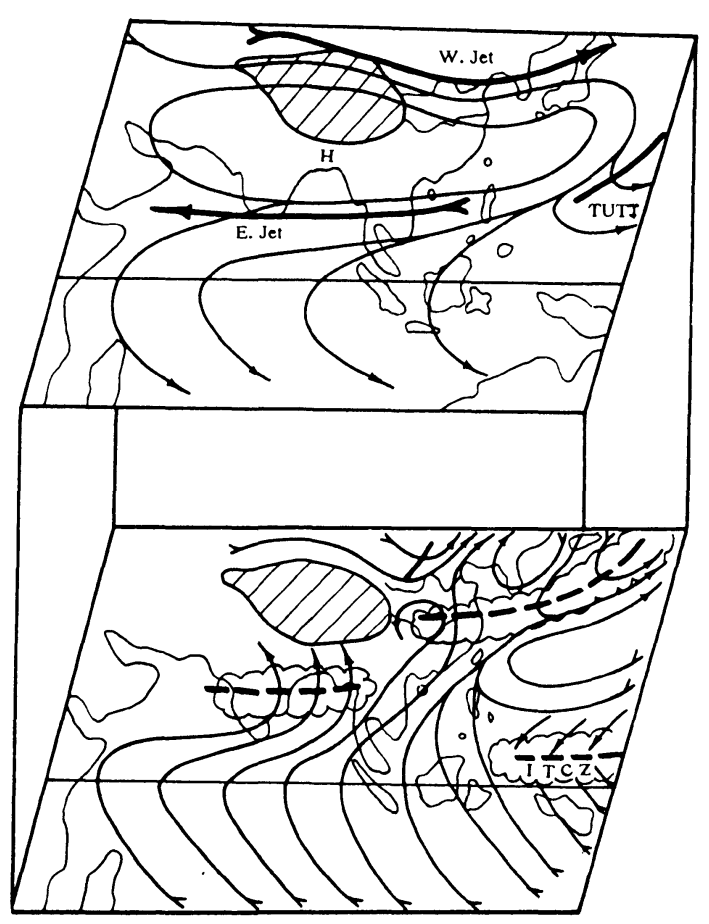

Fig. 4. The schematic of large-scale circulation features associated with the Meiyu and Baiu in East Asia. The upper panel represents the $200 \mathrm{hPa}$ condition and the lower panel the $850 \mathrm{hPa}$ condition $(\mathrm{Si}$, 1989).

study (Wang and Li, 1982) has indicated that the beginning and maintenance of the Meiyu is also related to the cross-equatorial airflow at about $110^{\circ} \mathrm{E}$. Therefore, the Meiyu in China is developed directly under the influence of the Indian southwest monsoon or the cross-equatorial airflow coming from the Southern Hemisphere. Based on the recent statistics of the relationship between the onset date of SW monsoon over Bombay and the beginning date of the Meiyu made by Chen et al. (1984) on the average, the onset of the Indian monsoon is three days earlier than the beginning of the Meiyu, nearly similar to the previous finding. Kato (1989) has pointed out that the onset and maintenance of the Meiyu seems to result from the enhancement of the lowlevel southerly wind toward the Meiyu front around China which occurs nearly simultaneously with the onset of the South Asian summer monsoon.

Figure 4 is a schematic map of the large-scale circulation features characterizing the Meiyu in East Asia. It can be seen that the Meiyu front is formed through the meeting of monsoon airflows and the polar cold airmass or transformed polar continental airmass. The monsoon airflows come partly from the Indian Ocean and partly from the cross-equatorial airflow over South China Sea and West Pacific (Si, 1989). They eventually merge into a strong south- 
west monsoonal flow over the South China and the valleys of the Yangtze River and the Huaihe River. The onset of the Meiyu is nearly simultaneous with occurrence of the stable and persistent southwest monsoon in this region (Lin et al., 1983). Concurrently, the isopleth of $\theta_{s e}=340^{\circ} \mathrm{K}$ also abruptly moves over this region, indicating the inflow of large amount of warm and moist air into the Meiyu region.

The ending of the Meiyu in the Yangtze Valley is characterized by the replacement of the southwest monsoonal airflow by the southeast wind. This condition is created by the westward extension of the subtropical high over the West-Pacific which is accompanied by the advance from the south to the north and from the region off the coast inland of the southeasterly monsoon at the southwestern flank of the subtropical high. This kind of southeasterly wind prevailing after the Meiyu season, that starts the mid-summer of the year, is the so-called Bozhao wind by $\mathrm{Su}$ Dongpo, a noted poet in Song Dynasty.

During the Meiyu season, a persistent flow pattern is observed at the mid-and high latitudes over Eurasia, characterized by the blocking situation upstream $\left(90^{\circ} \mathrm{E}\right)$ of and or downstream $\left(150^{\circ} \mathrm{E}\right)$ of the Meiyu region at $50-70^{\circ} \mathrm{N}$ and a nearly zonal flow prevailing in latitude band of $35-50^{\circ} \mathrm{N}$. The short-wave troughs often move southeastward down to the valley of the Yangtze River, bringing cold air over this region, thus forming and maintaining the stationary Meiyu front (Zhang et al., 1986). Japanese meteorologists (Ninomiya and Muraki, 1986; Ninomiya, 1989) have found that the development of a warm ridge over the Mongol-Sibirsk Plateau (Baiu ridge) and cold trough elongated from the Bering Sea cylone to China (Baiu trough) were the noteworthy features during the Meiyu season in middle and high latitudes.

Over the valley of the Yangtze River and the Huaihe River, a nearly east-west oriented wind shear line is observed that corresponds to the position of the Meiyu front. The precipitation is generally located in the area between the Mieyu front and 700 hPa-shear line, about 5 latitude wide (Qiu and Ding, 1979). The southwest airflow is found to the south of the shear line while the easterlies of the back part of the modified continental cold high are observed to the north of the shear line. There are often two vortices along the shear line (mainly near the surface), mostly located in the Sichuan Basin (100$\left.107^{\circ} \mathrm{E}, 28-33^{\circ} \mathrm{N}\right)$ and the eastern part of the Dabie mountains $\left(114-117^{\circ} \mathrm{E}, 31-34^{\circ} \mathrm{N}\right)$, respectively. The strong wind axis in the southwest monsoonal airflow originating in the Indian Ocean often reaches the intensity of a low-level jet $(12 \mathrm{~m} / \mathrm{s})$. It splits into two branches while propagating eastward, with the major one traversing the Indo-China Peninsula and Gulf of Tonkin and then flowing into the Meiyu

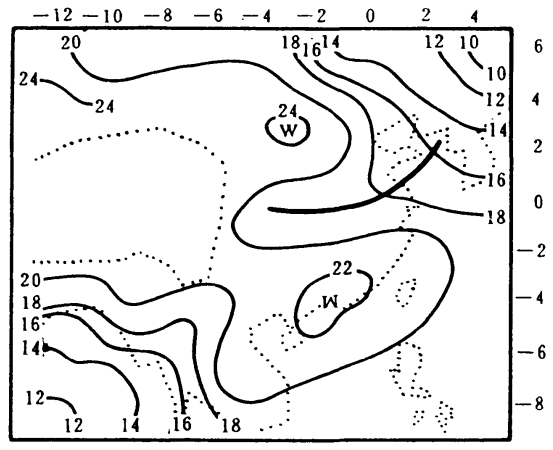

Fig. 5. The composite temperature field at 850 hPa. Unit: ${ }^{\circ} \mathrm{C}$. (Zhang, 1990).

region.

The salient feature of the temperature field at 850 $\mathrm{hPa}$ during the Meiyu season shows up in the sandwiched pattern, with a cold thermal trough extending southwestward into the Meiyu region and warm areas located to the north and the south of it (Fig. 5). A similar analysis was made also by Takahashi (1989). The temperature of the northern warm area may sometimes be higher than that of the southern warm area, due mainly to strong sensible heating from the underlying surface and rapid temperature rise in the lower layer over the extensive arid or semiarid areas from Takla Makan to North China (40$50^{\circ} \mathrm{N} / 80-120^{\circ} \mathrm{E}$ ) in the early summer (Kato, 1985 ; Kato, 1987). The shearline is located within the cold thermal trough. Above $700 \mathrm{hPa}$, the temperature field is characterized by an east-west oriented warm belt capping over the low-level cold trough.

The moisture field indicates an extensive region of high moisture from the South China Sea to the valley of the Yangtze River. This high moistureloading region nearly corresponds to the location of a low-level jet that has a large component toward the Meiyu front and constitutes the prominent dew point front or the energy front with dry and cold air on the northern side, with the moisture (dewpoint) gradient of $4-7^{\circ} \mathrm{C} / 5$ latitude, significantly greater than temperature gradient $\left(1.5^{\circ} \mathrm{C} / 5\right.$ latitude). Therefore, the Meiyu front is mainly characterized by the moisture contrast across the front rather than the temperature contrast.

From the satellite images, one may clearly see a continuous cloud band over the region of the Meiyu, generally located to the south of the shear line at $700 \mathrm{hPa}$. The convective cloud masses or ensembles are often observed to be embedded in the extensive cloud band (Qiao et al., 1986a). The maxima of total cloudiness, thunderstorm activity, precipitation amount and convective cloudiness are basically located at the same latitude, about $30^{\circ} \mathrm{N}$. The convective cloudiness nearly accounts for about $30 \%$ of total cloudiness. The thunderstorm activity, precipitation and convective cloudiness have the nearly 
same width (5 latitude wide). Therefore, the heavy rainfalls during the Meiyu period are of the nature of convective precipitation.

The Meiyu is mainly produced by the Meiyu front and that has been addressed by numerous investigators (Xie, 1956; Qiu and Ding, 1979). Compositing structures of the Meiyu front (Qiao et al., 1986b) also show an apparent structure of a frontal zone, mainly above $500 \mathrm{hPa}$. The thermal gradient is directed from the cold air in the north to the warm air in the south. Above the frontal zone, there is an upper-level westerly jet at $200 \mathrm{hPa}$. At $700 \mathrm{hPa}$, the structure of the frontal zone can not be detected, only a shear line is observed that forms between lowlevel easterly and westerly winds. The low-level jet at about $700 \mathrm{hPa}$ seems to be downward extension of the upper-level jet. This problem will be discussed later. Below $850 \mathrm{hPa}$, there is generally a temperature gradient, indicating the existence of the frontal zone which is the so-called Meiyu front as often seen on the daily weather maps.

To the north of the heavy rains, there is a deep layer of dewpoint front, with the mean gradient of $7-9^{\circ} \mathrm{C} / 5$ lat., while to the south there is a vertical deep layer of high moisture. Therefore, the Meiyu front essentially is a dewpoint front or energy front, with the thermal contrast or gradient being less distinctive.

The meridional cell associated with the Meiyu region is unique, being broadly similar to the condition of the ITCZ in the tropics. Over the heavy rains of the Meiyu, there is a deep ascending airflow that results from a merging of the cold airflow coming from the north and the monsoonal airflow coming from the tropics. The vertical axis of ascending airflow is nearly erect. This belt of confluent airflows corresponds to the Meiyu front. There is a huge monsoon cell to the south of the region of the Meiyu heavy rainfalls, with the descending branch located equatorward of $10^{\circ} \mathrm{N}$. Overall, this is a positive meridional cell, as indicated previously by Qiu and Ding (1979).

A study on the structure and the vorticity budget of a Meiyu system for the period June 10-15, 1974 also revealed similar results (Chen and Chang, 1980). They pointed out that during the mature and decaying stages of the monsoon trough (nearly corresponding to the Meiyu front), the structure of the eastern sector (southern Japan) and the central section (East China Sea) is different from that of the western section (southeastern China). In the former two sectors the structure resembles a typical mid-latitude baroclinic front (like a polar front) with strong vertical tilting toward an upper-level, coldcore low and a strong temperature gradient. On the other hand, the western sector assumes a semitropical disturbance with an equavalent barotropic, warm-core structure, a weak horizontal temperature gradient and a rather strong horizontal wind shear in the lower troposphere. Based on the study of the dynamic process for vertical motions in the above three sectors of the Meiyu front, Tsay and Chen (1981) further found that, at the decaying stage, the circulation in the eastern sector still partially maintained the characteristics of a mid-latitude system, while the western sector behaved like a tropical system. A more detailed comparison is summarized in Table 1.

In the Taiwan area, the Meiyu rainfall is identified as one of the most destructive and disastrous natural hazards ( $\mathrm{Wu}, 1990)$. The heavy regional precipitation (in excess of $100 \mathrm{~mm}$ daily), especially the flash flood, may cause serious local hazards. For instance, the flash flood that occurred in central Taiwan on August 7, 1959 led to great property loss, including 699 deaths and 377 missing persons. The flash floods that occurred on May 28 and September 3, 1981 as well as June 3 and 10, 1984 led to great property loss individually, which all resulted from heavy rainfall. But, it should be pointed out that the Meiyu (or Baiu) in the Taiwan area generally occurs in the period of late spring to early summer when the transition circulation regime from the northeast monsoon in winter to the southwest monsoon in summer occupies the area. As indicated previously, the mean position of this phenomenon migrates northward with time in the area to the south of the Yangtze River Basin and Japan islands. It is over southern China and Taiwan area in the period of mid-May to mid-June. Therefore, the Meiyu in the Taiwan area in fact corresponds to the presummer rainy season over South China. The rainbearing frontal zone in the Taiwan area is the eastward extension of the major planetary frontal zone in East Asia.

\section{(3) Rainfalls over North China during the summer monsoon}

The rainy season in North China starts in the middle or last part of July. July and August are two months with frequent occurrence of heavy rainfalls in North China. The excessively heavy rainfalls in the first part of August, 1963 (" 63.8 " heavy rainfall) in the valley of the Haihe River, in the middle part of July, 1958 ("58.7" heavy rainfall) in the middle valley of the Yellow River, and in the first part of August, 1977 in the northern part of Shanxi Province all occurred during such a time period. Climatologically, the summer rainfalls in North China occur when the summer monsoon reaches its peak stage and the northernmost position. The 10-yr mean $850 \mathrm{hPa}$ wind field in July (Liang, 1987) shows that the southwesterly monsoon consistently prevails over South China, North China and Northeast China. To the south of the Yangtze River, the frequency of occurrence of the southwest airflow has its 
Table 1. A comparison between the Meiyu in China and Baiu in Japan

\begin{tabular}{|c|c|c|}
\hline & Meiyu in China & Baiu in Japan \\
\hline Large-scale aspects & $\begin{array}{l}\text { (1) Dual-blocking highs }\left(90^{\circ} \mathrm{E} \text { and }\right. \\
\left.150^{\circ} \mathrm{E}\right) \text { and nearly zonal airflow }(30 \\
\left.-50^{\circ} \mathrm{N}\right) \text {, and single blocking high } \\
\left(100^{\circ} \mathrm{E}\right) \text { and upper-level cold vortex } \\
\text { in Northeast China; } \\
(2) \text { The global summer monsoon is es- } \\
\text { tablished and the subtropical anticy- } \\
\text { clone over West-Pacific is enhanced; } \\
\text { (3) The upper westerly jet is located } \\
\text { in latitude band } 30-50^{\circ} \mathrm{N} \text {. }\end{array}$ & $\begin{array}{l}\text { (1) Baiu trough and the Baiu ridge } \\
\text { are formed, similar to the single- } \\
\text { blocking type. The rainfall activity } \\
\text { of the Baiu front is greatly controlled } \\
\text { by the Baiu trough (or cold air); } \\
(2) \text { A more northern latitude ( } 60- \\
70^{\circ} \mathrm{N} \text { ) of the upper westerly jet }\end{array}$ \\
\hline Frontal structure & $\begin{array}{l}\text { (1) A weak or nearly absent hori- } \\
\text { zontal thermal gradient, strong mois- } \\
\text { ture gradient and nearly moist neu- } \\
\text { tral or convectively unstable stratifi- } \\
\text { cation; } \\
\text { (2) The Meiyu front is related to a } \\
\text { shear line between the southerly and } \\
\text { northerly winds, with a rather strong } \\
\text { wind shear in the lower troposphere; } \\
\text { (3) An equivalent barotropic warm } \\
\text { core aloft. }\end{array}$ & $\begin{array}{l}\text { (1) A typical midlatitude front with } \\
\text { a strong horizontal temperature gra- } \\
\text { dient and moisture gradient; } \\
\text { (2) The Baiu front is located } 1500 \\
\mathrm{~km} \text { south of the Baiu trough; } \\
\text { (3) A prominent vertical tilt toward } \\
\text { an upper level cold core. }\end{array}$ \\
\hline Cloud and rainfall zone & $\begin{array}{l}\text { (1) Stable and continuous precipita- } \\
\text { tion and cloud band with convective } \\
\text { rain masses embedded; } \\
\text { (2) Very weak baroclinicity }\end{array}$ & $\begin{array}{l}\text { (1) A major cloud system includ- } \\
\text { ing deep convective clouds; } \\
\text { (2) Weak convectively unstable con- } \\
\text { ditions and fairly strong baroclinicity. }\end{array}$ \\
\hline Meso-scale structure & $\begin{array}{l}\text { (1) Intense Meiyu rainfall is pro- } \\
\text { duced by successive passage and de- } \\
\text { velopment of a medium-scale (meso- } \\
\alpha \text { scale) frontal depression which is } \\
\text { composed of a few meso- } \beta \text { scale dis- } \\
\text { turbances; } \\
\text { (2) Medium-scale depressions, con- } \\
\text { fined to the layer below } 500 \mathrm{hPa} \text {, have } \\
\text { a } 1000-1500 \mathrm{~km} \text { horizontal scale while } \\
\text { the meso- } \beta \text { scale disturbances have a } \\
\text { wavelength of } 150-200 \mathrm{~km} \text {, with con- } \\
\text { siderably faster eastward propagating } \\
\text { speed than the medium-scale distur- } \\
\text { bances. }\end{array}$ & $\begin{array}{l}\text { (1) The Baiu front is made up of a } \\
\text { number of medium-scale depressions, } \\
\text { separated by relatively clear skies; } \\
\text { (2) Some of medium-scale depres- } \\
\text { sions may develop into significant } \\
\text { Baiu frontal cyclones around Japan } \\
\text { where the thermal gradient is rela- } \\
\text { tively large. }\end{array}$ \\
\hline Low-level jet (LLJ) & $\begin{array}{l}\text { (1) LLJ is often formed under the } \\
\text { condition of an eastward extending } \\
\text { Indian monsoon and further turning } \\
\text { to southerly winds over the South } \\
\text { China Sea; } \\
\text { (2) LLJ has a super-geostrophic char- } \\
\text { acter; } \\
\text { (3) Significant southerly component } \\
\text { toward the Meiyu front, thus causing } \\
\text { moisture convergence. }\end{array}$ & $\begin{array}{l}\text { (1) Forming in NW or N rim of the } \\
\text { subtropical anticyclone; } \\
\text { (2) A relatively small horizontal scale; } \\
\text { (3) Some of LLJ are consequences of } \\
\text { feed-back of Baiu rainfall. }\end{array}$ \\
\hline
\end{tabular}

peak value of the year, generally with $60 \%$ or greater. To the north of the Yangtze River, the frequency may reach $40-50 \%$. At 700 and $500 \mathrm{hPa}$, the southwest monsoon airflow advances northward up to the eastern part of North China and southeastern part of Northeast China. As the southwest 
monsoon penetrates deeply into North China and the southern part of Northeast China $\left(40-50^{\circ} \mathrm{N}\right)$, the monsoon rainy belt moves northward up to the same regions which is generally located in the southwest monsoon airflow to the south side of the shear line. The fluctuation of intensity of the East Asian summer monsoon is closely related to the precipitation variation in North China (Shi and Chao, 1983). Based on the statistics for 1958-1979, the precipitation is generally above-normal when the summer monsoon is relatively active in North China (for example, 1973, 1977, 1979) and vice-versa (for example, 1972, 1974, 1976, 1979, 1980), with the exception of some individual years. Therefore, the activity of the summer monsoon in North China sets the stage for the occurrence of the rainy season in this region. Its short-term fluctuation is to some extent associated with the coresponding fluctuation of precipitation in North China, although not closely, due to the complexity of rainfall process.

One interesting finding by Liang (1988) is the good correlation relationship of the rainfalls between North China and the Indian monsoon rainfall in summer. By use of the long time series of precipitation data in India and Tianjin $\left(39^{\circ} \mathrm{N} / 118^{\circ} \mathrm{E}\right)$ which is representative of the North China region, Liang (1988) has found that the summer rainfall between India and North China has a stable and significant positive correlation relationship, especially with a fairly consistent occurrence of droughts and flooding events in these two regions (Fig. 6). The statistics have shown a marked similarity of annual range of the precipitation amount, with the summer rainfall amount accounting for nearly the same percentages of total annual amount. A possible link of precipitation between these two regions is associated with the development of the monsoon troughs in India. When this condition is true, the monsoonal airflow in India and the significant low-level jet (southerly) in China will be enhanced simultaneously, thus causing an increase in precipitation in these two regions.

Based on an analysis of 33 cases of heavy rainfalls in North China for 1958-1976 (Ding et al., 1980), the circulation patterns and synoptic situation favorable for heavy rainfalls in North China have been identified. The heavy rainfalls mainly occur under the circulation situation of the blockage of the low-pressure trough coming from the west by the stationary high downstream. When the long-wave trough is located at $100-110^{\circ} \mathrm{E}$, it is most favorable for occurrence of heavy rainfalls, because in such case the North China region is located in advance of this long-wave trough. The high over the Sea of Japan is a key circulation feature for creating the heavy rainfall in North China (Cao, 1990). It may persist for 3-5 days, thus playing a dual role: blocking of the eastward-moving upstream troughs and producing an easterly or southeasterly low-level jet

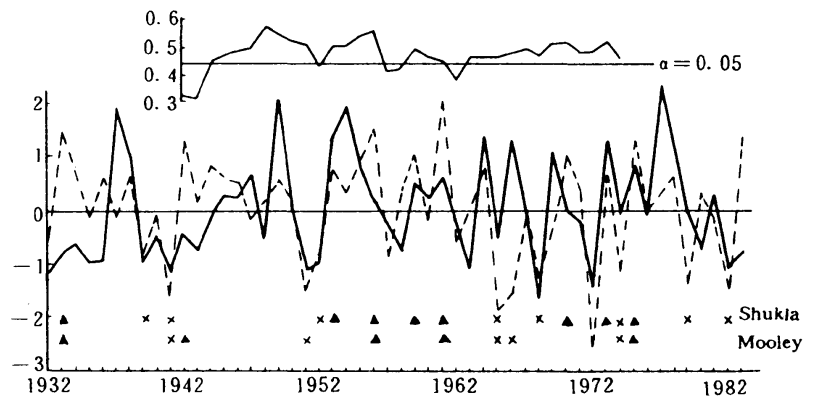

Fig. 6. The standardized time series of precipitation amount for the whole Indian region (dashed curve) and Tianjin $\left(39^{\circ} \mathrm{N} / 118^{\circ} \mathrm{E}\right)$ (full line) for 1932-1983. The top panel represents the running average correlative coefficient, triangles flooding years, and crosses dry years. (Liang, 1988).

at its southern flank that may transport moisture into the regions of the Yellow River valley and the eastern part of Hebei Province. If there is a typhoon to the south of the high, the easterly airflow would get further intensified and maintained.

The rain-bearing synoptic systems often observed in North China are the upper troughs with an accompanying cold front, the wind shear line in the warm sector, the extratropical cyclones in the valley of the Yellow River, and the upper cold vortex. In general, the eastward moving upper trough with a cold front can seldom produce heavy rainfalls with the rainfall amount being $100-200 \mathrm{~mm}$ during the duration of rainfall. However, if the upper trough is deepening and slows down its movement or is connected with a low vortex (for example, the SW vortex) in the south, it can cause heavy rainfalls with a rainfall amount greater than $200 \mathrm{~mm}$. The shear line in the warm sector in North China is defined as a low-level east-west oriented wind shear line that generally is generated in the Shandong Province or the Yangtze River-Huanghe region. Then, as the southerly airflow to the south of it enhances, often reaching the intensity of a low-level jet, the shear line moves northward, and at the same time so does the associated rain region. This type of rain-bearing synoptic system is mainly observed to the east of the Taihang mountain range. The heavy rainfall is, in general, located in the region in advance of the shear line, or between the shear-lines at the surface and $700 \mathrm{hPa}$, with the axis of the shear line tilting northward. Therefore, this pattern of rainfall is in many ways similar to that caused by the warm front. Based on the analysis of 12 cases of the warm shear lines, in 9 of them were found the existence of lowlevel jets that have a wind speed of $20-30 \mathrm{~m} / \mathrm{s}$. 


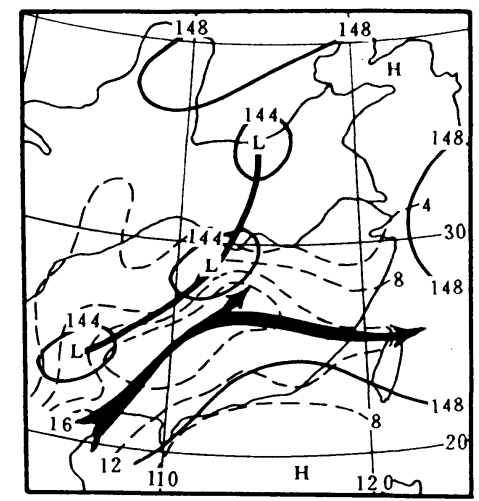

Fig. 7. The weather map at $850 \mathrm{hPa}$ at 00 GMT May 16, 1977. The solid line represents the isopleth of geopotential height (decameter), the dashed lines isotachs $(\mathrm{m} / \mathrm{s})$, and the heavy arrow the jet axis. (Huang, 1986).

\section{The low-level jet associated with summer monsoon rainfalls}

The low-level jet (LLJ) is often observed and is highly correlated with the precipitation, in particular the heavy rainfall, during the summer monsoon season (Ding et al., 1980). The LLJ is frequently located at $1.5-3 \mathrm{~km}(850-700 \mathrm{hPa})$, to the south of and parallel to the fronts or shear lines such as the Meiyu front.

Based on the statistics of the relationship between the low-level jet $(>16 \mathrm{~m} / \mathrm{s})$ and the heavy rainfalls in Guangdong Province made by use of data for MayJune of 1970-1973 (Huang, 1986), it has been found that out of 19 processes of low-level jets, 16 were accompanied by heavy rainfalls, with 1-5 days lagging. Therefore, the probability of occurrence of heavy rainfalls is as high as $84.2 \%$ once there is a low-level jet. The statistics for Guangxi Province (1957-1974) have revealed a similar result.

The heavy rainfalls related to the low-level jet are generally located in the left front sector of the jet where there is the maximum convergence. The statistics have indicated that about $80 \%$ of heavy rainfalls occurred in this manner.

The genesis and development of low-level jets are attributable to two types of synoptic process. The first type is associated with the intensification of the subtropical high and development of low-pressure systems to the west of the jet. When the trough in the southern branch of the westerlies moves eastward to the east of the Tibetan Plateau, it often may induce the genesis of a low-vortex or low pressure trough at low-level. As these systems move farther eastward and develop, the pressure gradient will enhance. If at this time the system can acquire a development, the ageostrophic wind will increase, thus augmenting the wind speed to generate the low-

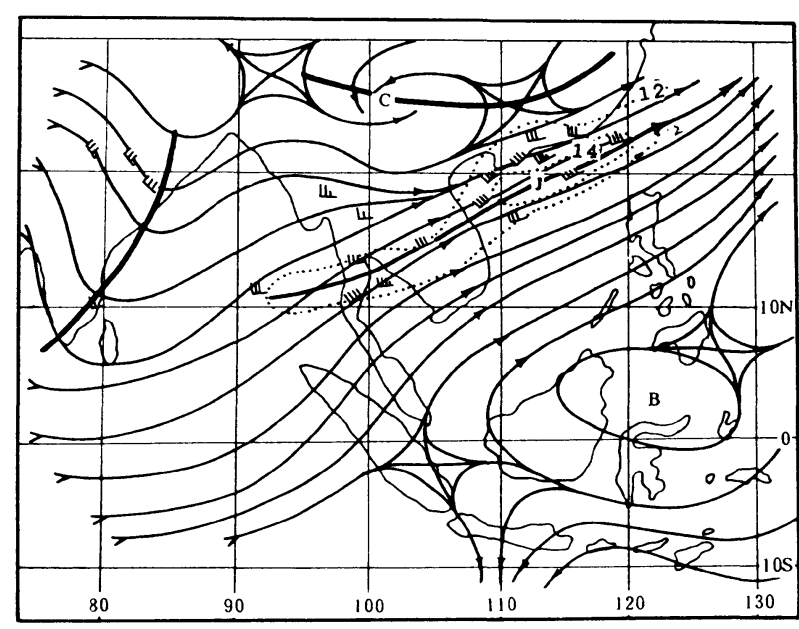

Fig. 8. The streamline chart at $850 \mathrm{hPa}$ at 00 GMT May 30, 1977. The bold line with arrow denotes the jet axis; the dashed line isotach. Units: $\mathrm{m} / \mathrm{s}$. (Zhong and Liang, 1984).

level jet. Figure 7 is an obvious example. The generation of a low-level jet at $850 \mathrm{hPa}$ on May 16, 1977 is closely associated with the eastward movement of a SW vortex from the Sichuan Province, which is a kind of low-level vortex generated on the eastern slope of the Tibetan Plateau under the effect of the southerly monsoonal airflow.

The second type of synoptic process responsible for the formation of a low-level jet is related to the enhancement of the southwest monsoon over the Indo-China Peninsula and the northern part of the South China Sea. The wind maximum is first observed in the prevailing southwest monsoon airflow over the Indo-China Peninsula, then it gradually moves northward and eventually influences the region of South China (Fig. 8). This type of low-level jet usually is relatively strong and has a larger scale and more persistent duration (Zhong and Liang, 1984). Sometimes, the low-level jet may also result from the enhancement of cross-equatorial airflows. In these cases, the low-level jet over South China is, as a matter of fact, part of the large-scale monsoonal airflow.

The vertical circulation associated with a lowlevel jet is characterized by the upward motion ahead of the jet streak and the downward motion behind the jet streak. The left front sector has a strong convergence where the heavy rainfall usually occurs. The low-level jet is a very warm and moist high-speed airflow. The dewpoint temperature has the marked positive anomaly along and to the left of the jet axis, with $700 \mathrm{hPa}$ being most moist ( $\mathrm{Li}$ et al., 1988). The warm tongue of temperature always runs with the jet zone. The low-level jet may transport abundant moisture northward. 
The wind field associated with the low-level jet is super-geostrophic ( $\mathrm{Li}, 1980)$. The strong ageostrophic component would excite the inertial gravity wave, thus causing the genesis of meso-scale systems. This contention has been documented with the relationship between wind field and precipitation during the pre-summer rainy season. The low-level jet has a marked diurnal variation in wind speed (Huang, 1986). This condition is in many ways similar to that of the Somali Jet or the Mid-west of the United States.

As observed during the pre-summer rainy season over South China, the low-level jet is also a major component of the Meiyu season that is closely related to the occurrence of heavy rainfalls. The low-level jet during the Meiyu heavy rainfalls is a super-geostrophic southwesterly jet in the lower troposphere (Sun, 1986). But, at the present time, the argument about the cause of formation of this jet is controversial. Japanese meteorologists suggest that the low-level jet in the Meiyu regions results from the up-and down exchange of momentum by cumulus convection in the heavy rainfall region (Ninomiya and Akiyama, 1974); some investigators stressed that the occurrence of the low-level jet is related to the development and eastward movement of low pressure systems in the west; others pointed out that the low-level jet streak is a result of inertial oscillation in the planetary boundary layer. Recently, Uccellini and Jonhnson (1979) have documented that the development of a low-level jet results from momentum-mass adjustment and is coupled with the upper-level jet. In general, the isallobaric wind induced by mass adjustment in the exit region of the upper-level jet streak may cause the low-level jet to develop. But, the statistics and case studies of formation of low-level jet during the Meiyu season (Huang and Gao, 1982; Si et al., 1982) indicate that most of the low-level jets (about $76 \%$ ) occur below the entrance region, rather than the exit region of the upper-level jet streak. This is feature of the low-level jet during the Meiyu rainstorm period. Figure 9 shows this relationship ( $\mathrm{Si}, 1988$ ). The developmental condition for this kind of low-level jet in the entrance region is that, first, there is an extensive area of southwesterly wind and, then, as the upper-level jet moves eastward, the ageostrophic equilibrium near the streak of the upper-level jet causes a region of upper level divergence in the right sector of the entrance region of jet, thus leading to convergence through mass adjustment and the production of isallobaric winds in the lower troposphere.

This kind of isallobaric wind may cause the development of a low-level jet while acting upon the low-level southerly winds. Xiao and Chen (1984) also revealed similar evidence, i.e., the low-level jet occurred at distance of $550 \mathrm{~km}$ to the south of the upper level jet entrance region at $200 \mathrm{hPa}$ (Fig. 10).
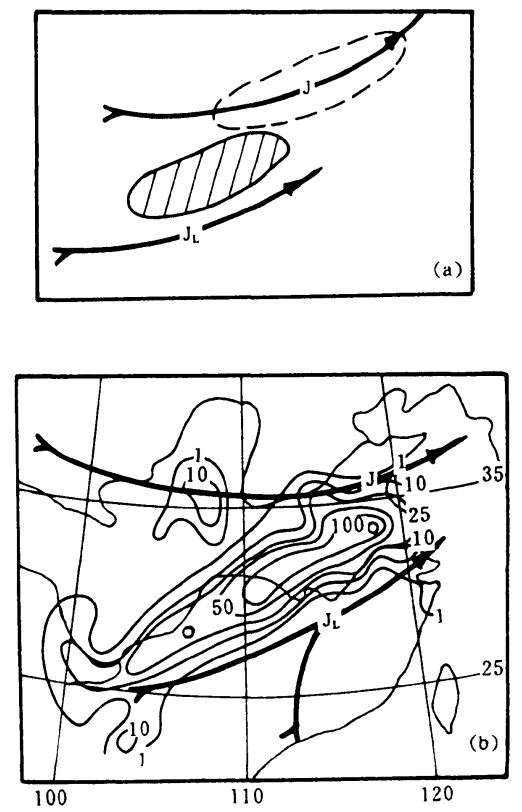

Fig. 9. Total rainfall amount for 00 GMT 11 July-00 GMT 12 July, 1969 and its relation to the upper-level jet $(\mathrm{J})$ and low-level jet $\left(\mathrm{J}_{\mathrm{L}}\right)$. Units: $\mathrm{mm}$. ( $\left.\mathrm{Si}, 1988\right)$.

Extensive precipitation occurred over the region between axis of the upper-level jet and the axis of the low-level jet (Also see Fig. 9). This region corresponds to the area of high temperature and moisture to the north of the subtropical high. They discussed the acceleration of the low-level jet by use of the interaction of advective and adjustment processes and the instability of the inertial gravitational wave during the adjustment process. They further made a compositing picture of the cross-section of the jet stream across the shear line by use of eight cases for 1968-1971, and documented celarly the coupling relationship between the upper-level jet and the lowlevel jet. It can be found that the wind maximum of the upper-level jet is located at $200 \mathrm{hPa}$, with a wind speed of $48 \mathrm{~m} / \mathrm{s}$, while the low-level jet has its maximum of about $20 \mathrm{~m} / \mathrm{s}$ at $700 \mathrm{hPa}$, with the shear line in between.

In addition, Chen (1989) pointed out that this coupling may also occur between the low-level jet and the tropical easterly jet in South Asia. This vertical coupling is essential for the occurrence of heavy precipitation and the latent heat release acts as a positive feedback processes for such vertical coupling.

Recently, Chou et al. (1990) have made a numerical simulation of the Meiyu front and the associated low-level jet, showing concurrent development of upper-level easterlies and low-level westerlies equatorward of the front for the subtropical experiments. The appearance of upper easterlies suggests that LLJ may be a secondary ciculation equatorward of 

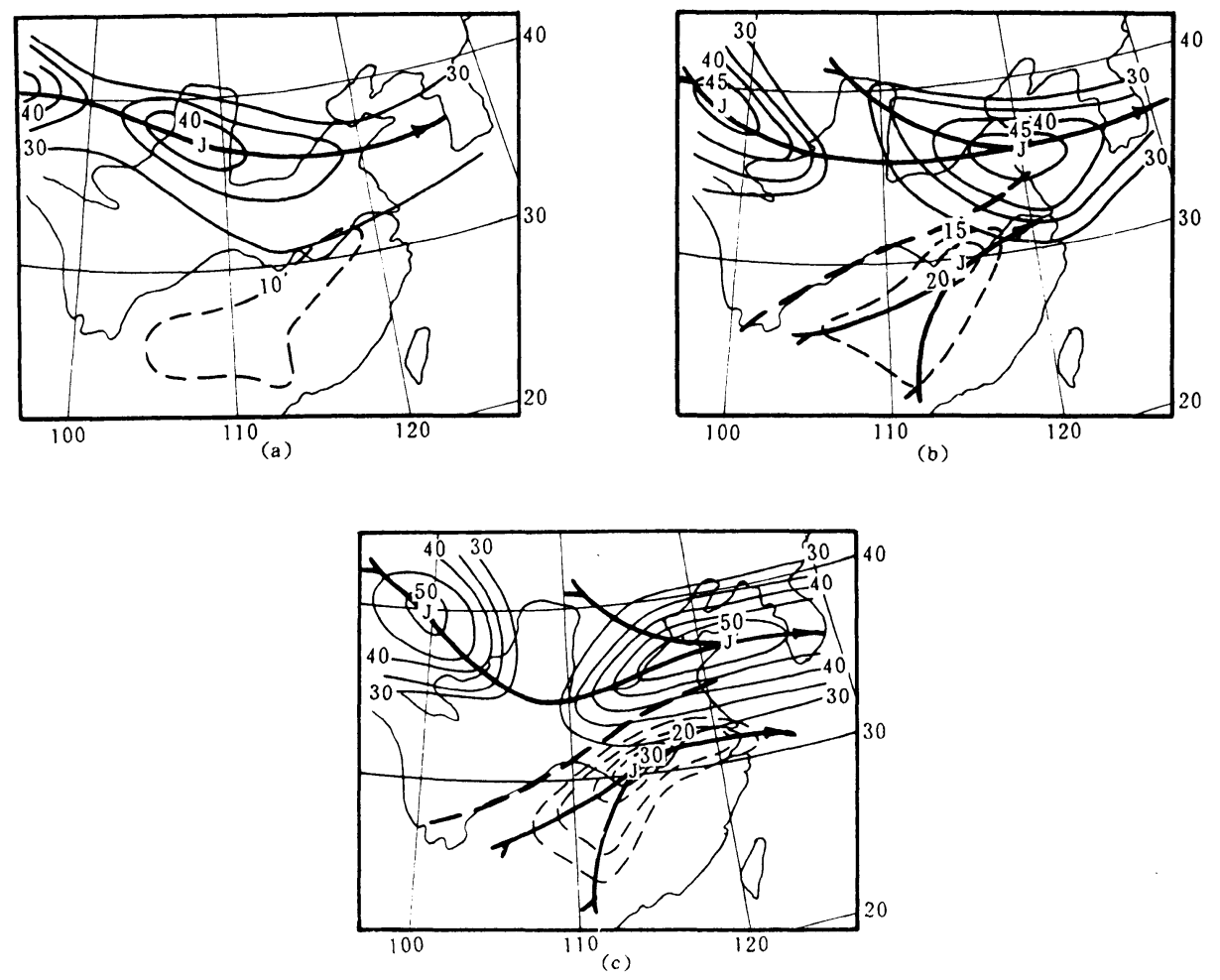

Fig. 10. The patterns of jet streams at $200 \mathrm{hPa}$ (solid lines) and $700 \mathrm{hPa}$ (dashed lines) (a) for $12 \mathrm{GMT}$ July 10, (b) 00 GMT July 11, and (c) 12 GMT July 11, 1969. (Xiao and Chen, 1984).

the front which is revealed by the meridional-vertical streamfunction. This "reverse Hadley" cell is thermally direct, and its lower-branch poleward flow is stronger in the more moist subtropical cases and coincides with the development of a LLJ. The Coriolis torque exerted by it provides a westerly acceleration that can develop and maintain the LLJ. Cumulus convection and especially a slantwise structure in developing the reversed Hadley cell and the LLJ is quite important. These numerical experiments also lend some support to the mechanism of the LLJ development suggested by Chen (1982).

The low-level jet plays a very important role in the formation of the heavy rainfall in North China, as it does for the Meiyu or the pre-summer rains in South China. Based on the analysis of 33 cases of the North China rainstorms, in 21 of them (with the maximum wind axis greater than $12 \mathrm{~m} / \mathrm{s}$ ) was found the existence of low-level jets, accounting for $64 \%$ of total cases. Among 21 cases of low-level jets, 15 were the southerly or southwesterly low-level jets, and 6 were the easterly low-level jets. The latter developed either over the sea or on the land when there is typhoon activity (Tao et al., 1980). On August 21 and 22, 1966, the easterly low-level jet ran from Japan, Korea to North China and Northeast China, thus contributing much to the heavy rainfall of 800 mm in Pingding County, Shanxi Province, through transport of a large amount of moisture from the sea. At the same time a typhoon was located to the south of Japan.

Under the influence of a large-scale southwesterly airflow, the wind streak of the southwesterly lowlevel jet tends to propagate northeastward. Whenever the wind streak arrives in Henan Province, the heavy rains occur in Hebei Province downstream, other conditions being favorable. Once the wind streak propagates up to Hebei Province, the heavy rainfall moves out of this region. For the easterly low-level jet, a similar situation is true. Whenever its wind streak arrives in the Korean Peninsula, heavy rainfall is often observed to occur in North China. An example of a markedly downstream propagating low-level jet is shown in Fig. 11. The wind streak along the jet axis was located in Guangxi Province on 12 GMT July 27, 1966. As the subtropical high moved northward and extended westward, the wind streak in this southerly low-level jet propagated northward. On the next day, it arrived in the Huaihe River-the Yellow River regions (Fig. 11b). At this time, it caused a heavy rainfall in the eastern part of Hebei Province, with a maximum rainfall amount of about $200 \mathrm{~mm}$. On the third day, the low-level jet further moved over the Bohai Bay, ending the process of heavy rain in Hebei Province. 


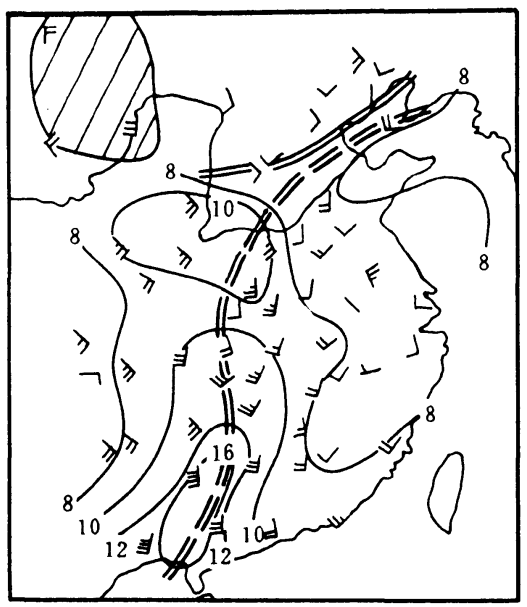

(a)

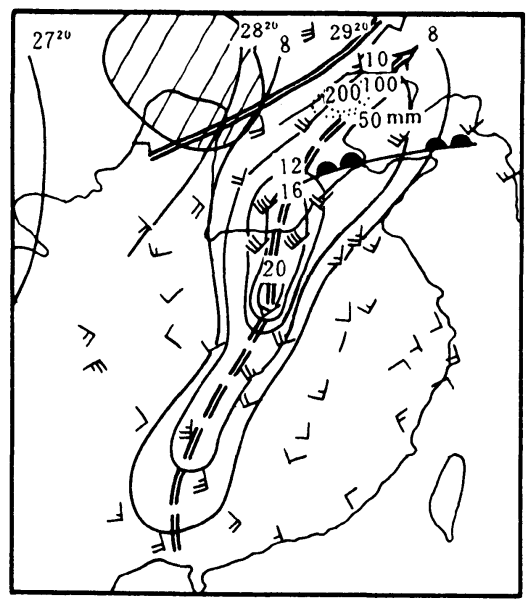

(b)

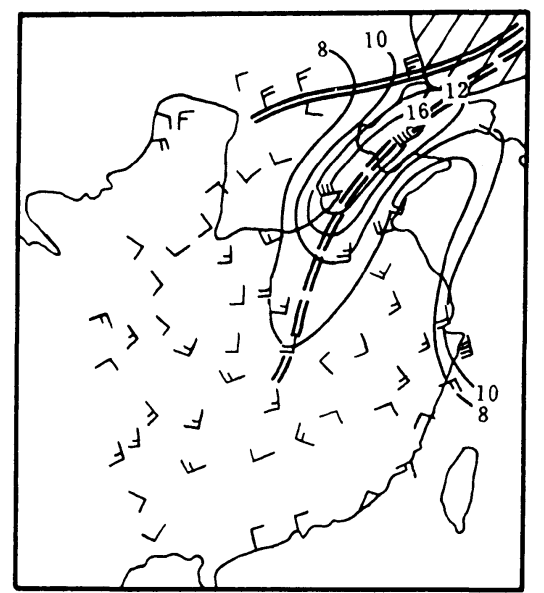

(c)

Fig. 11. (a) The $850 \mathrm{hPa}$ wind field at 12 GMT July 27, 1966; (b) same as (a), but for 12 GMT July 28; (c) same as (a), but for 12 GMT July 29. (Ding et al., 1980).

\section{Meso-scale features of precipitation sys- tems during the summer monsoon season}

It has been recognized that the heavy rainfall during summer monsoon season are mainly caused by meso-scale synoptic systems. These meso-scale weather systems are generally embedded in a quasistationary, large-scale frontal cloud or precipitation band. They are often convective in nature, and propagate along the large-scale frontal cloud band. The meso-scale analysis of several dozen pre-summer heavy rainfalls has indicated that every process of the pre-summer heavy rainfall in South China is associated with meso-scale systems, generally including over ten rain masses (rainfall intensity $>10$ $\mathrm{mm} / \mathrm{hr}$ ). These rain masses have a horizontal scale of $30-40 \mathrm{~km}$, mean life span of 5 hours and mean movement speed of $25 \mathrm{~km} / \mathrm{hr}$, steered by the mean wind at 500 or $700 \mathrm{hPa}$. The formation of rain masses is largely controlled by local terrain, and sea breeze to a lesser extent, with the preferred origin region observed in the valley area of rivers, lake area and horn-shaped terrains (Liang and Bao, 1980).
The meso-scale systems during the pre-summer heavy rains may be classified into the following types: the meso-scale cyclone, the meso-scale anticyclone, the meso-scale shearline, the convergence line in the southerlies, the dewpoint front and energy front, and the meso-scale convective systems and the squall (Jiang et al. 1990). A brief description of some of them has been given by Lian and Bao (1980). The meso-scale cyclones are generated along the shearline, especially at the cross point of two shear lines. They may produce excessively heavy rainfalls. For example, 25 meso-scale cyclones were observed during the process of the case of the heavy rainfall "77.5" (May 27-June 1, 1977, the eastern part of Guangdong Province). That produced an accumulative rainfall amount of over $500 \mathrm{~mm}$, over an extensive area.

The heavy rainfalls during the Meiyu period are mainly generated by the meso-scale disturbances which are embedded within and propagate along the large-scale Meiyu cloud and rain band or frontal zone with horizontal scale of several thousand kilometers. A number of observational studies have doc- 
umented that there are two types of mesoscale disturbances during the Meiyu period: meso- $\alpha$ scale and meso- $\beta$ scale disturbances. A considerable amount of rainfall during the Meiyu season is due to these disturbances. The meso- $\alpha$ scale disturbance is termed as the intermediate-scale or medium-scale or subsynoptic scale disturbance by Japanese meteorologists (Matsumoto and Ninomiya, 1971). It is a kind of non-developing low-pressure system with the horizontal scale of several hundred kilometers and a period of 20 hours embedded within the Meiyu rain band. It is most apparent in the lower layer and has a thermal structure of warm upper part and cold lower part. This kind of thermal structure is exactly the same as that of the intermediate scale disturbance which brings about heavy rains around Japan. A cold core in the lower troposphere and a significant warm core in the middle and upper troposphere over the intermediate-scale disturbance is found. This system in general propagates successively northeastward along the Meiyu front and is in good correspondence to the meso-scale rain bands and rainfall centers. It is the major rain-bearing synoptic system causing the short-term temporal and spatial variations of Meiyu precipitation. On the other hand, the meso- $\alpha$ scale disturbance may provide a very favorable condition for the production of thunderstorms and rainstorms during the Meiyu season, including the abundant supply of moisture, warm and moist unstable stratification and strong low-level convergence. The meso- $\alpha$ scale systems during the Meiyu period may be further classified into two types: a Changjiang Huaihe shear line over the valleys of the Yangtze River and Huaihe rivers, and a low vortex. The Changjiang (Yangtze)-Huaihe $\left(112-120^{\circ} \mathrm{E}\right.$ $30-35^{\circ} \mathrm{N}$ ) shear line is the major synoptic system bringing about the Meiyu heavy rainfalls in this region. Based on the statistics of 1954-1958, 110 shear lines for April-September for 5 years were observed, of them 84 were accompanied by heavy rainfalls, accounting for $76 \%$. The process of the shear line may cause the rainstorms for 5-7 days. A recent study has indicated that the Changjiang-Huaihe shear line in fact is a reflection of the airflow pattern of the meso-scale cloud and rain bands during the Meiyu period. It is a relatively shallow system with the vertical extent confined in the layer below $500 \mathrm{hPa}$ and being especially obvious below $850 \mathrm{hPa}$. The shear line is also of baroclinic structure, tilting northward. There is a marked belt of airflow divergence aloft lying over the low-level shear line. The temperature and pressure fields corresponding to the meso-scale rain band are mainly characterized by the apparent thermal and dew-point frontal zone, but the frontal zone does not extend very high, in general, only up to about $850 \mathrm{hPa}$. There is a belt of convective heating in the meso-scale rain band.

So far, there has been no agreed-upon viewpoint of the dynamic mechanism of the formation of this kind of intermediate-scale rain band or shear line. Some investigators argue that it is likely a baroclinic wave of the $\mathrm{Ri}<1$ because $\mathrm{Ri}$ number of the Meiyu frontal zone is very small under the mean condition and it is very easy to satisfy the criteria of unstable growth of the intermediate-scale disturbance, while other investigators suggest that this disturbance should be an unstable wave incorporating the effect of cumulus convection. Lu and Wang (1988) also have a similar argument, indicating that the development of the intermediate-scale disturbance results from the combined baroclinic-CISK condition. Recently, Zhang (1988) has further discussed the meso-scale stability of the baroclinic airflow, showing that in the case of a thin sheared layer and small $\mathrm{Ri}$, the Eady mode may extend down to the régime of the meso- $\alpha$ scale wave. The characteristics thus obtained still have the quasi-geostrophic property. This mechanism seems to be used for explaining the propagating-type meso-scale disturbance in the Meiyu front.

There are at least two kinds of meso-scale low vortices that may bring about heavy rains during the Meiyu season. One kind of low vortex is the SW (southwest) vortex. This low vortex is one kind of the meso-scale synoptic system generated on the leeside of the Tibetan Plateau. It is most evident at the 850-700 level, while at the surface and above $500 \mathrm{hPa}$ it is not easy to detect. After the $\mathrm{SW}$ vortex forms, it tends to be stationary locally if there is no upper-level trough to steer it out of the Sichuan Basin. However, if the vortex is steered out, it may move eastward along the Meiyu shear line in most cases, and in some cases moves northeastward or southeastward. Meanwhile, it can cause the heavy rainfalls along its track. When an extended trough is connected with the SW vortex to build up the flow pattern of the northern trough and southern vortex, this synoptic condition may often cause extensive heavy rainfalls. An other kind of low-vortex is the intermediate-scale cyclone with a horizontal scale of $1000-3000 \mathrm{~km}$. Figure 12 is an example of the heavy rainfall caused by an intermediate-scale low vortex that initially was generated in the Henan Province $\left(110-115^{\circ} \mathrm{E}, 22-36^{\circ} \mathrm{N}\right)$ and then moved eastward. The starting time of the heavy rainfall was recorded after 18 GMT, 20 June, 1972. During its genesis and development, altogether three heavy rainfalls occurred that were located in the eastern part of the Tabie Mountain, i.e. the southeastern sector of the Henan low vortex. Note the second episodes of heavy rainfalls shown in Fig. 12b (Zhang and $\mathrm{Li}$, 1979).

The intermediate-scale cyclone is different from the synoptic-scale cyclone in that the latter is closely related to the trough in the upper troposphere, while the former is laid aloft at $500 \mathrm{hPa}$ by flat and 

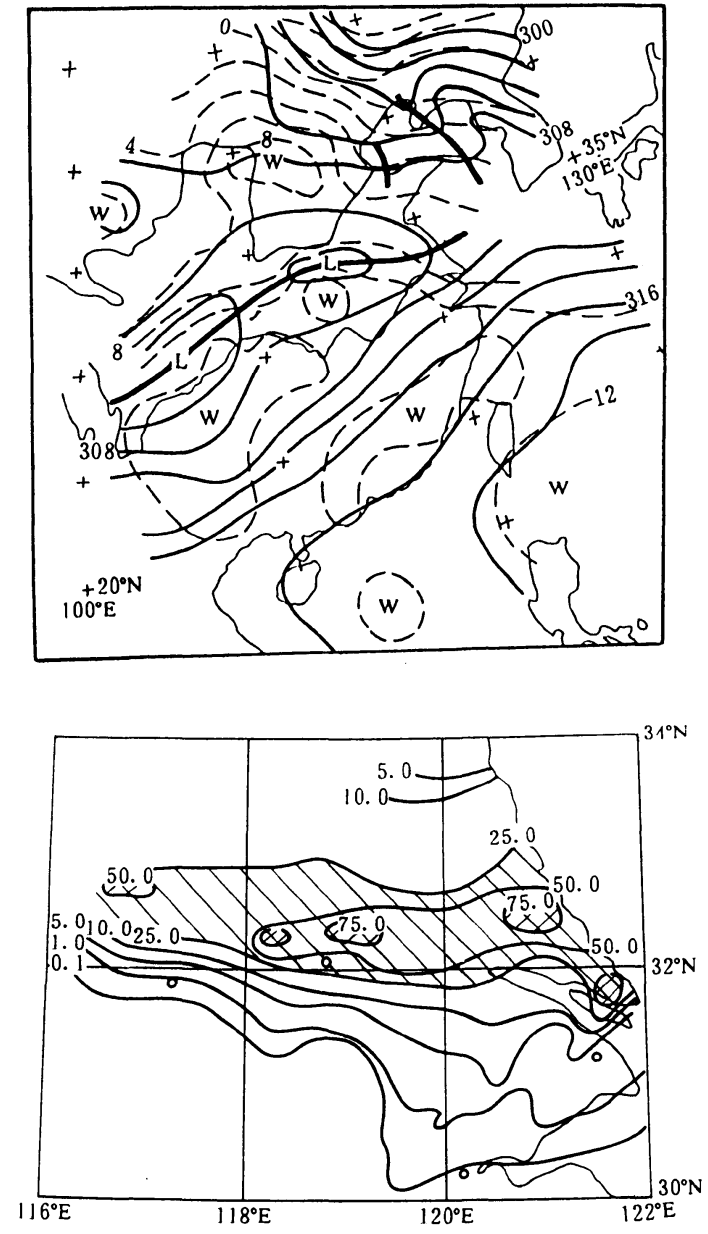

Fig. 12. (a) The $700 \mathrm{hPa}$ synoptic map at 00 GMT June 21, 1972. The full lines represent isopleths of geopotential height; the dashed lines isotherms. Units: decameter; (b) the distribution of rainfall amount 06-12 GMT June 21, 1972. Units: mm (Zhang et al., 1979).

straight westerlies (Qiu and Ding, 1979). The cyclonic disturbance is mainly confined to the layer below $500 \mathrm{hPa}$ and in the upper troposphere there is a high-pressure ridge lying over it. Therefore, this kind of low vortex is also characterized by negative vorticity at the middle level or at the upper level. The thermal structure of the intermediate scale cyclone shows a warm core in the upper troposphere. The differences in the structure between the synoptic-scale cyclone and the intermediatescale cyclone suggest a possibly different dynamic mechanism of their formation. The former is in most of cases initiated by a baroclinic mechanism, while the latter is greatly dependent upon the release of condensational latent heat, as indicated by Si (1976) and Chen et al. (1980). That is to say, the intermediate-scale cyclone is generated through the CISK mechanism. But, some of the intermediate- scale cyclones may also gain growth from the baroclinic energy source. Jin (1982) analyzed the structure of an intermediate-scale disturbance over the valley of the Yangtze-Huaihe Rivers, indicating that this disturbance formed in the low-level cold frontal zone. The genesis and development of the low vortex has a significant relationship to the release of the available potential energy in relation to the baroclinicity of the tropospheric frontal zone. Zhao (1988) also emphasized the nearly similar result based on his study of energetics of cyclogenesis on Meiyu front. He pointed out that at the developmental stage, the baroclinic energy conversion was highly significant, especially in the middle and upper troposphere. Zhao et al. (1982) simulated the genesis and development of a meso- $\alpha$ scale low-vortex and found that the meso- $\alpha$ scale vortex may be generated in the large-scale synoptic system. At the genesis stage, the dynamic factors play a major role, while at the developmental stage the condensational latent heating produced by precipitation plays an important role in the maintenance and intensification of the meso- $\alpha$ scale low-vortex. Utilizing a 10-layer moist meso-scale model, Huang et al. (1987) simulated a heavy rainfall process during the Meiyu season, with a special emphasis on the structure and evolution of the intermediate-scale system. They found that the low-level vorticity field, especially the low-level positive vorticity center, is closely related to the centers of heavy rain. The maxima of 3 -h precipitation developed and moved along with the vorticity maximum center. While the low-level vorticity maximum moved near or under the center of negative vorticity at the upper level it intensified considerablly and, concurrently, the upward motion and precipitation were also intensified. These results are broadly consistent with the observational evidence.

Due to the unavailability of meso- $\beta$ scale data in China, very little work has been done of meso- $\beta$ scale systems. Little has been known of their structures and dynamical characteristics. The Meiyu experiment over the middle and lower reaches of the Yangtze River (1980-1984) for first time provided the possibility of studying this system on the horizontal scale of $250-250 \mathrm{~km}$, with the denser network of the upper-air and surface observations. It has been found that the meso- $\beta$ scale system occurs in advance of the forward tilting minor wave trough which is located near the Meiyu cloud and rain bands, on the right side of the upper-level jet, and the left side of the low-level jet. In general, this system is associated with the meso-scale shear line. To the south of the meso-scale shear line, there is a belt of strong wind or a conveying belt of the warm and moist air. To the left of this belt, rain masses or rainstorms occur. At the time of development of rain masses or rainstorms, the shear line has a marked temperature gradient, which possibly indicates that 
the meso- $\beta$ scale system at this time has significant baroclinicity at low-level. At the middle and upper level the meso- $\beta$ scale system is of the nature of significant convective systems, with convergence found at low and middle levels, and divergence at the upper level due to the release of condensational latent heat. In the boundary layer, there is dry and cold descending air produced by the drag effect of precipitation particles. The rainstorm is generally located somewhere between the meso-high and meso-low.

Sun (1990) analysed the activity of meso- $\beta$ scale, large amplitude gravity waves during a Meiyu rainfall event and their relationship to environmental fields. The gravity waves may be characterized by the connecting line of rainfall peaks. The gravity wave has an average wavelength of $200 \mathrm{~km}$, an amplitude of $2 \mathrm{hPa}$, a period of 6-8 hours and a translational speed of $60-80 \mathrm{~km} / \mathrm{h}$. The intense rainfall occurred in the region of convergence behind the meso-scale wave trough and in advance of the wave ridge.

\section{Atmospheric heat sources associated with summer monsoon precipitation and their effect on the change in the general circula- tion in East Asia}

Numerous authors have investigated the heat sources and sinks in summer over the Asian monsoon region, including Luo and Yanai (1984), and Chen and Li (1985). They pointed out that the strongest heat sources in the summer monsoon season are located over the Bay of Bengal and central India rather than over the Tibetan Plateau, because the former has a maximum heating rate of $8^{\circ} \mathrm{C} /$ day while the latter has a maximum heating rate of about $1^{\circ} \mathrm{C} /$ day. Other heat sources are found over the region to the east of the South China Sea and the tropical West Pacific. These heat sources play a yery important role in driving the regional monsoon circulations.

Firstly, a detailed discussion of the heat budget over the South China Sea and South China will be given below, mainly based on the study by Ju and Luo (1987). They utilized the dataset of the period April-June, 1981 to investigate the relationship between heat sources during the build-up of the summer monsoon in Asia and the tropical circulation. The temporal variations of the areal mean, vertically-integrated $\mathrm{Q}_{1}$ (apparent heat source) and $\mathrm{Q}_{2}$ (apparent moisture sink), have nearly similar trends of variation, indicating that the major contribution of $Q_{1}$ was made from the condensational latent heating. Prior to 25 April, $\mathrm{Q}_{1}$ and $\mathrm{Q}_{2}$ were negligibly small, generally lower than $20 \mathrm{w} / \mathrm{m}^{2}$. This condition corresponds to the winter situation, i.e., the absence of a heat source over Southeast Asia. After 11 May, $Q_{1}$ and $Q_{2}$ significantly increased as much as one order of magnitude, with $\mathrm{Q}_{1}>100$

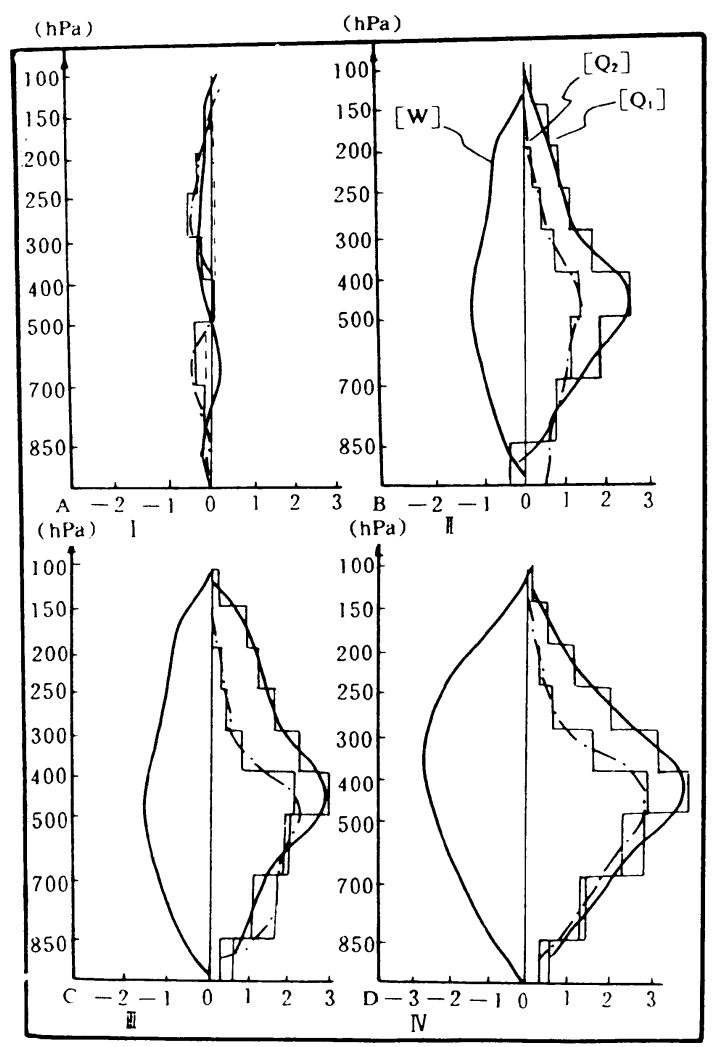

Fig. 13. Mean profiles of $\left[\mathrm{Q}_{1}\right],\left[\mathrm{Q}_{2}\right]$ and $[\omega]$ for four stages (see the text) of summer monsoon development over the domain 95$120^{\circ} \mathrm{E}, 5^{\circ} \mathrm{S}-30^{\circ} \mathrm{N}$ Unit: ${ }^{\circ} \mathrm{C} /$ day for $\left[\mathrm{Q}_{1}\right]$ and $\left[\mathrm{Q}_{2}\right] ; \mathrm{hPa} / \mathrm{h}$ for $\omega$. (Ju and Luo, 1987).

$\mathrm{w} / \mathrm{m}^{2}$. The analysis of flow patterns at $850 \mathrm{hPa}$ also shows a significant change around 11 May. Therefore, the date of 11 May is defined as the onset day of the summer monsoon of 1981 over Southeast Asia (including the Indo-China Peninsula, the South China Sea and South China). As previously indicated, the summer monsoon in this region usually sets in much earlier than the counterpart over the Indian Peninsula.

Figure 13 is the mean profiles of $\left[Q_{1}\right],\left[Q_{2}\right]$ and $[\omega]$ for four different stages of the monsoon development. The late spring stage (Stage I: 1-7 April) was characterized by a negative $\left[Q_{1}\right]$ over nearly the whole troposphere, indicating the dominance of radiation cooling, and a negative $\left[\mathrm{Q}_{2}\right]$ below $450 \mathrm{hPa}$, indicating the presence of evaporative cooling. At the initial stage (Stage II: $3-9$ May) $\left[\mathrm{Q}_{1}\right]$ and $\left[\mathrm{Q}_{2}\right]$ began to increase, with $\left[\mathrm{Q}_{1}\right]$ having $2.4^{\circ} \mathrm{C} /$ day at $450 \mathrm{hPa}$ and $\left[\mathrm{Q}_{2}\right] 1.5^{\circ} \mathrm{C} /$ day. Due to insignificant separation of the peaks of $\left[Q_{1}\right]$ and $\left[Q_{2}\right]$, it is inferred that frontal continuous precipitation could dominate this region. At the onset stage (Stage III: 10-16 May) $\left[\mathrm{Q}_{1}\right]$ and $\left[\mathrm{Q}_{2}\right]$ rapidly enhanced, with the peak of $\left[\mathrm{Q}_{1}\right]$ of $2.8^{\circ} \mathrm{C} /$ day at $450 \mathrm{hPa}$ and the peak of $\left[\mathrm{Q}_{2}\right]$ of $1.6^{\circ} \mathrm{C} /$ day at $500 \mathrm{hPa}$. At the prevail- 
ing stage (Stage IV: 1-7 June), $\left[\mathrm{Q}_{1}\right]$ and $\left[\mathrm{Q}_{2}\right]$ further increased with the peaks of $\left[\mathrm{Q}_{1}\right]$ and $\left[\mathrm{Q}_{2}\right]$ being of $3.8^{\circ} \mathrm{C} /$ day and $2.9^{\circ} \mathrm{C} /$ day, respectively. Note the increasing contribution of the condensational heating at the later two stages, though convective activity seems to be somewhat inactive over Southeast Asia and the South China Sea.

The analysis of the flow pattern for the same period indicated that the development of the atmospheric heat source seemed to occur about 10 days prior to the onset of the summer monsoon. This may imply the driving effect of the diabatic heating field on the establishment of the summer monsoon over the South China Sea and Southeast China. The intraseasonal fluctuation of the summer monsoon over the South China Sea and South China may be clearly observed after its onset, mainly showing up in the active-break cycle. Correspondingly, the heat source and sink should also assume a similar variation, due to the significant interaction between them. In the summer of 1979 (31 May-31 August) when the summer monsoon prevailed over the South China Sea, there were two active episodes (June-the middle part of July; 26 July-14 August) and two break episodes (14-25 July, 15-31 August). The break monsoon usually occurred when the ridge of the subtropical high over West Pacific extended into the South China Sea. Duan (1983) estimated the heat sources and sinks averaged for the active period and the break period of 1979 summer, respectively, defining the above-described two active episodes (64 days) as Period I and the two inactive episodes (29 days) as Period II. During Period I, the vertical velocity is upward below $250 \mathrm{hPa}$ while in Period II, the downward motion dominated this region, nevertheless, a deep layer of mean positive vertical velocity was also observed.

The profiles of mean $\mathrm{Q}_{1}$ and $\mathrm{Q}_{2}$ are rather consistent with those of the vertical velocity (Fig. 14), with the heat source $\left(Q_{1}>0, Q_{2}>0\right)$ in the whole layer during Period I observed. The maximum heating was found at $500 \mathrm{hPa}$, and the maximum cooling for Period II is also found at $500 \mathrm{hPa}$. Note the nearly identical magnitudes of $\mathrm{Q}_{1}$ and $\mathrm{Q}_{2}$, indicating that the condensational latent heating assumes the major portion of the diabatic heating. For the inactive period of the summer monsoon, the negative $\mathrm{Q}_{1}$ may be interpreted as the major contribution of long-wave radiation cooling and evaporative cooling to the diabatic heating.

The Meiyu period in the valley of the Yangtze River is one of the major rainy seasons in China. During the process of rainfall in the Meiyu, a large amount of condensational heat may be released, thus making a major contribution to the heat source and sink in this region. Luo and Yanai (1984) estimated $\mathrm{Q}_{1}$ and $\mathrm{Q}_{2}$ over the Yangtze River valley over eastern China and show apparent heating and drying

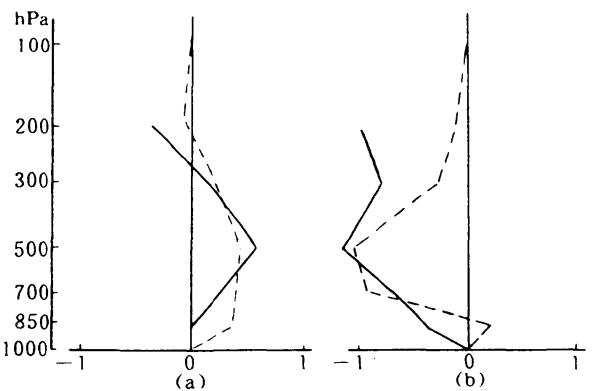

Fig. 14. The mean profiles of $\mathrm{Q}_{1}$ (solid line) and $\mathrm{Q}_{2}$ (dashed line) averaged for Period I (left panel) and Period II (right panel) of 1979 summer for the domain of the South China Sea. Units: 10 cal./g.s. (Duan, 1983).

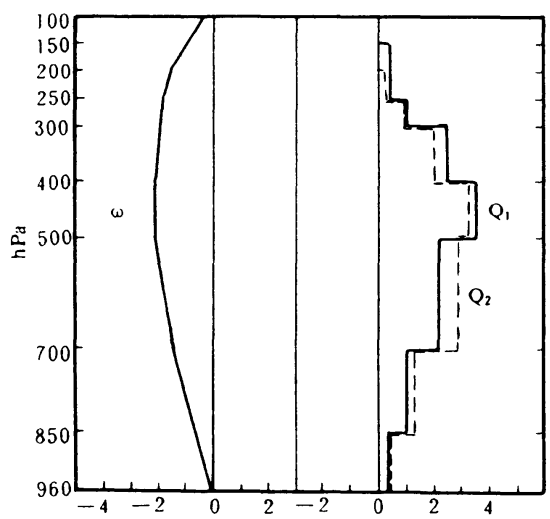

Fig. 15. Forty-day mean (the Meiyu period of 1979) vertical distribution of the areal mean (the middle and lower valleys of the Yangtze River: $22.5-32.5^{\circ} \mathrm{N} / 109-121^{\circ} \mathrm{E}$ ) vertical $\mathrm{p}$-velocity $(\mathrm{hPa} / \mathrm{h})$, heating rate $\mathrm{Q}_{1} / c_{p}$ (k/day) and drying rate $\mathrm{Q}_{2} / c_{p}$ (k/day) over Yangtze River valley. (Luo and Yanai, 1984).

(moisture sink) of nearly the same magnitude and nearly the same heights for the $\mathrm{Q}_{1}$ and $\mathrm{Q}_{2}$ peaks; this, according to Luo and Yanai, is a signature of steady, continuous stratiform rain (Fig. 15). This condition is quite different from that in other regions. Later, Ding and $\mathrm{Hu}$ (1988) used a similar method to estimate the heat source and sink over the Yangtze River valley for the 1984 Meiyu season. They found that in this year the precipitation was mainly convective in nature. This markedly distinctive result reflects a great interannual variability of the heat source and sink during the Meiyu season, which may result from the different large-scale circulation conditions or may be due to different rainbearing systems. However, for the 1983 Meiyu season, the continuous precipitation seemed to dom- 

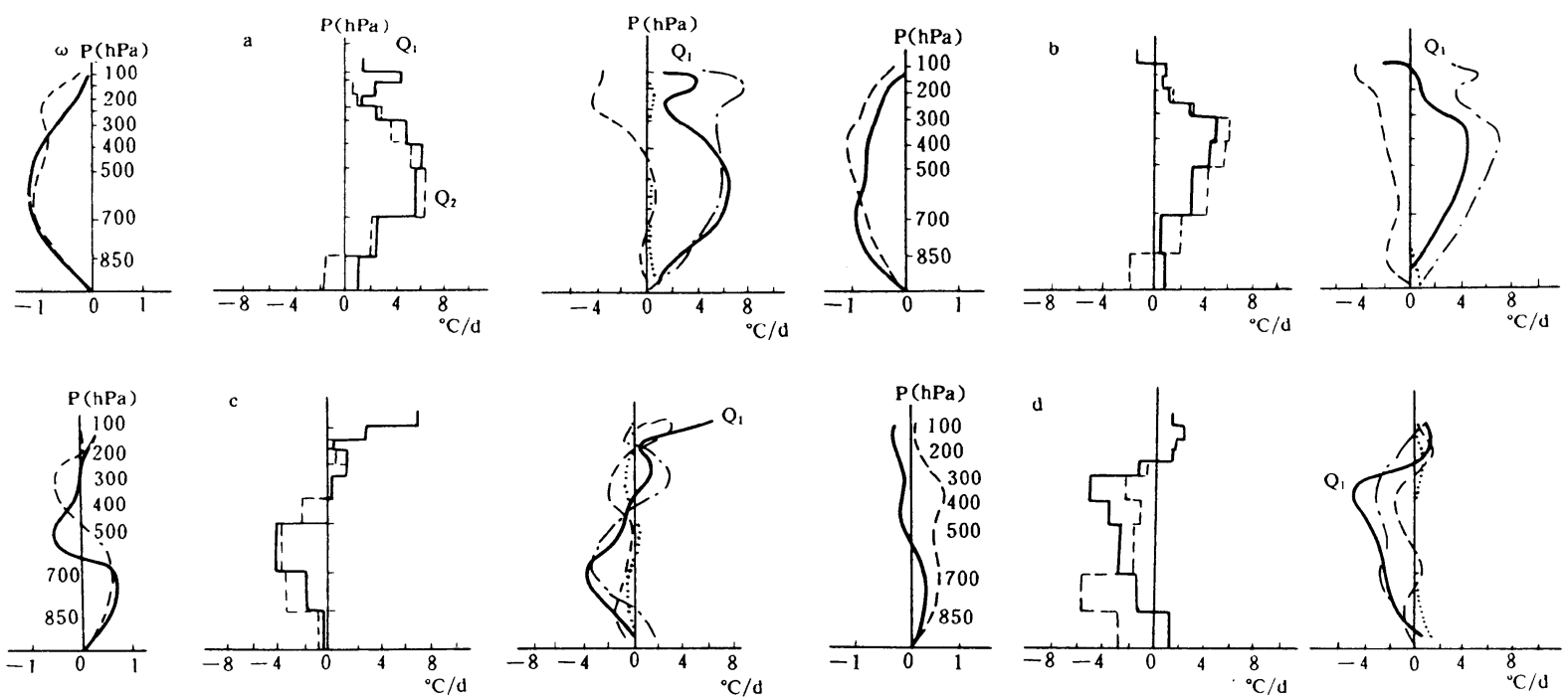

Fig. 16. The vertical p-velocity $(\omega)$ (left), $\mathrm{Q}_{1}$ and $\mathrm{Q}_{2}$ (middle) and various components of $\mathrm{Q}_{1}$ (right; the solid line represents $\mathrm{Q}_{1}$; the dashed line the horizontal advective term, the dashed-dotted line the vertical advective term and the dotted line the local change term) averaged for four time spans: (a) episode (1-17 May, 25 May-3 June) prior to 1983 Meiyu, (b) during 1983 Meiyu (9 June-17 July), (c) episode (23-26 July) post to 1983 Meiyu and (d) dry spell (averaged for 18-24 May, 4-8 June, 18-22 July, and 27-31 July). The solid lines in the left panel denote 00 GMT values and the dashed lines 12 GMT values. The solid line in the right panel indicates $\mathrm{Q}_{1}$ and the dashed lines $\mathrm{Q}_{2}$. Unit: ${ }^{\circ} \mathrm{C} /$ day for $\mathrm{Q}_{1}$ and $\mathrm{Q}_{2} ; 10^{-3} \times \mathrm{hPa} / \mathrm{s}$ for $\omega$ (Ding and Wang, 1988).

inate the middle and lower valley of the Yangtze River (Ding and Wang, 1988). Figure 16 gives the profiles of the vertical p-velocity, and $\mathrm{Q}_{1}$ and $\mathrm{Q}_{2}$ for the different episodes of 1983 Meiyu season. For the episode prior to the Meiyu season, the vertical velocity shows upward motion in the deep layer for 00 and 12 GMT. The profiles of $\mathrm{Q}_{1}$ and $\mathrm{Q}_{2}$ are very similar below $200 \mathrm{hPa}$, only with the $\mathrm{Q}_{1}$ peak slightly higher than that of $\mathrm{Q}_{2}$, indicating the dominance of continuous and stable precipitation. The maximum heating is $6-7^{\circ} \mathrm{C} /$ day, at $400-500 \mathrm{hPa}$. During the Meiyu period, $\mathrm{Q}_{1}$ and $\mathrm{Q}_{2}$ have similar shapes, with peaks of $Q_{1}$ and $Q_{2}$ found at the same height of 300-400 hPa. This implies weak convective activity and a predominance of continuous precipitation. The precipitation post to the Meiyu period was very weak. Note the downward motion below $600 \mathrm{hPa}$, an unfavorable condition for precipitation. $\mathrm{Q}_{1}$ and $\mathrm{Q}_{2}$ are negative below $400 \mathrm{hPa}$, indicating evaporative cooling. Above $400 \mathrm{hPa}, \mathrm{Q}_{1}$ and $\mathrm{Q}_{2}$ are positive, but their magnitudes are very small. During the dry episode, the downward motion dominated nearly the whole troposphere and $\mathrm{Q}_{1}$ and $\mathrm{Q}_{2}$ are negative in the deep troposphere. This cooling is created by long-wave radiative cooling, because the condensational heating is nearly zero and the sensible heating is confined to the lower layer.

It is very interesting to note that the heating process during the Meiyu season may be related to the seasonal transition from spring to summer in East China (Ding and $\mathrm{Hu}, 1988$ ). It has been pointed out that the general circulation over East Asia undergoes a distinct seasonal change in the early summer (normally in June). One major event characterizing this change is the nearly simultaneous occurrence of the onset of the Indian summer monsoon and the sudden northward shift of the subtropical westerly jet stream in East Asia, and the commencement of the Meiyu in the Yangtze River valley. This fact reflects the possible thermally-forced effect of heat source caused by much precipitation after the onset of the Meiyu in the large-scale circulation in East Asia.

\section{Numerical experiments and operational prediction of the summer monsoon pre- cipitation in China}

In the recent decade, Chinese meteorologists have developed several limited-area numerical models designed to simulate the evolution and structure of precipitating weather systems as well as the character of the precipitation area and amount. In this regard, numerous works have been focused on the precipitation of the Meiyu season. Starting from 1984, the operational precipitation numerical prediction was issued by national- and regional-level meteorological services using the limited-area primitive equation models on a short-term basis, with a special emphasis on the prediction of the Meiyu precipitation or heavy rainfalls.

During the period 11-15 July 1981, an extremely heavy rainfall occurred over the Sichuan Basin in 
China. Observational studies showed that this heavy rainfall was largely related to the formation of a medium-scale vortex (SW vortex) on the eastern slope of the Tibetan Plateau. Several investigators have simulated this heavy rainfall event (Zhou and $\mathrm{Hu}$, 1983; Chen and Dell'Osso, 1985; Kuo et al., 1988) by using different numerical models. Zhou and $\mathrm{Hu}$ (1983) pointed out the importance of the initial field and treatment of terrain features for adequate simulation of this event. They found that the main source of water vapor is over the South China Sea rather than the Bay of Bengal. The simulation by Kuo et al. (1988) indicated that the SW vortex formed completely within a broad southwesterly monsoon flow, possibly induced by the strong variations in terrain elevation. As the southwesterly monsoon current impinged upon the meso-scale Yun-Gui plateau, which extends from the southeastern corner of the main Tibetan Plateau, the low-level airflow was blocked. The air aloft descended into the Sichuan Basin to the lee of the plateau, creating cyclonic relative vorticity through vertical stretching. Differential surface friction and diabatic effects were not responsible for the initiation of the vortex. However, both latent heating and surface fluxes of sensible and latent heat were essential to the full development of the SW vortex (Anthes, 1990). The model predicted a $48-\mathrm{h}$ rainfall maximum of $213 \mathrm{~mm}$ over the Sichuae Basin, in good agreement with observations.

The meso-scale vortex or intermediate-scale vortex are frequently observed to develop and propagate along the Meiyu front, and some of them may bring about heavy rainfall, as indicated in Section 5 . The numerical experiments by Zhou et al. (1984) by using the fine-mesh model suggested that at the genesis stage of the vortex or low the dynamic condition such as change in wind field is important while at the development stage the condensational heating, especially convective heating, has a significant effect. Li et al. (1987) also simulated the Meiyu weather systems and associated heavy rainfall. During 19-20 June 1982 heavy rainfall fell over the Yangtze Valley, with more than $300 \mathrm{~mm}$ falling near the city of Wuhan. They simulated well the sub-synoptic scale convergence lines at low-and middle levels, strong cyclonic circulation and the divergent circulation aloft and predicted the position of the major rainbelt for this case relatively successively. In particular, they stress the critical role of interactions of the latent heat release and the low-and upper-level jets for the maintenance of the slowly-moving convective systems. Without latent heat, the model does not maintain the concentrated region of high relative vorticity, the low-level jet, and the intense rainfall. The important effect of latent heat release has been documented by the numerical simulations by Zhang (1990). He stressed that both large-scale and convective heating are very important for correct simulation of the Meiyu rainfall and low-level jets. In addition, even for 24-hr precipitation prediction, the radiative forcing can not be neglected, especially for nocturnal rainfall episodes.

Recently, Qian et al. (1991) used the global model at the UK Meteorological Office to numerically simulate the Meiyu onset and its rain belt. They found that the onset of the Meiyu and its rain belt are sensitive to the Tibetan Plateau and the water vapour conditions over the Bay of Bengal. For the case without the plateau or with a suppressed moisture supply from the Bay of Bengal, the position of rain belt was not simulated in a realistic manner and the predicted rainfall amount is far lower than the observed one.

In summary, in a large-scale perspective the above-described numerical simulations have identified at least four factors which are critical for the occurrence and maintenance of summer monsoon precipitation over China: the monsoonal airflow (mainly southwesterly airflow) and the low-level jet which is generally embedded in the large-scale monsoonal airflow, abundant moisture supply, mainly coming from the Bay of Bengal and the South China Sea, the large-scale terrain feature, in particular the Tibetan Plateau, and the latent heat release including large-scale and convective heating.

At present, there are two models of numerical precipitation prediction for operational use in China (Zou, 1989). One is the limited-area precipitation prediction model operated by the National Meteorological Center, Beijing, mainly for the prediction of precipitation distribution and occurrence timing over a rather large area, and its products are disseminated all over China. The other is the operational model of a limited-area numerical precipitation prediction for the Yangtze and the Huaihe River valleys operated by the Wuhan Weather Observatory, which has been designed and developed mainly for forecasting the rainstorms in the Meiyu season. Table 2 is the comparison of the basic characteristics of these two models.

A preliminary test and verification have been made on the forecasting capability and performance of these two models. The results show that these two models are both capable of forecasting precipitation in central China, and both are successful in "yes or no" forecasting as well as predicting rainfall areas. Their common problem, however, is that the predicted rainfall areas are unrealistically large while the rainfall intensity is too low. Relatively speaking, the rainfall areas predicted by the Wuhan model are smaller, and the location of rainfall, rainfall maxima and intensity are all better than the forecasts made by the Beijing limited-area model for the same areas, especially for the 12-36 hour forecasts of the maximum rainfall amount. It is there- 
Table 2. Comparison between two operational limited-area models

\begin{tabular}{|l|l|l|}
\hline & Wuhan & Beijing \\
\hline Validity & $0-24 \mathrm{~h} 12-36 \mathrm{~h}$ & $0-24 \mathrm{~h} 12-36 \mathrm{~h}$ \\
Initial time & $0000 \mathrm{Z}(\mathrm{GMT})$ & $0000 \mathrm{Z}(\mathrm{GMT})$ \\
Time of issue & $0700 \mathrm{Z}$ & $0800 \mathrm{Z}$ \\
Area & Limited & Limited \\
& E-W $290 \mathrm{~km}$ & $5000 \mathrm{~km}$ \\
& N-S $23000 \mathrm{~km}$ & $3400 \mathrm{~km}$ \\
Projection & Lambert & Polar-conical \\
Equation & Primitive & Primitive \\
Grid space & $100 \mathrm{~km}$ & $190.5 \mathrm{~km}$ \\
Layers & 5 & 5 \\
Initial wind field & Observed & Derived \\
Topography & Included & Not included \\
Boundary & Fixed & Nested \\
\hline
\end{tabular}

fore obvious that the increase of the horizontal resolution can improve precipitation prediction to a certain degree, as well as have a predictive capability of heavy rainfalls. Figure 17 is an example, indicating that the predicted area of heavy rainfall and its maximum made by the Wuhan model, which is associated with a low-level shear-line, are quite consistent with that observed, but the amount is smaller, only half $(56 \mathrm{~mm} /$ day $)$ of that observed. The next 24 hour forecast is also basically comparable. Recently, Guo et al. (1990) have also stressed the importance of increasing the horizontal resolution to improve precipitation prediction by the Beijing limited-area model. Their sensitivity experiments have shown that the predicted precipitation, both in the rain area and amount, made significant improvements as the horizontal resolution increased from 381 to $47.625 \mathrm{~km}$. The experiment with $381 \mathrm{~km}$ horizontal resolution for one rainfall event in North China on August 9, 1984, predicted a too-wide rainfall area and a 24-hour maximum precipitation of only about $46 \mathrm{~mm}$. With the $47.625 \mathrm{~km}$ horizontal resolution, a southwest-to-northeast-oriented rain belt with a maximum amount of $234 \mathrm{~mm}$ was predicted, which compares well with the observation. Another interesting result obtained by their experiments is the marked change of the relative contribution of convective and large-scale condensation to the total precipitation. With the increase of horizontal resolution, the relative contribution of convective condensation, computed by the Kuo's scheme, to the total precipitation decreases markedly, while the precipitation produced by grid-scale condensation forms a dominant proportion of the total precipitation.

Numerical precipitation prediction in China needs to be improved further, including both the horizontal and vertical resolutions, the processing of initial data and its initialization, physical parameterization, the prediction of the moisture flux convergence, the physical process in the planetary bound-
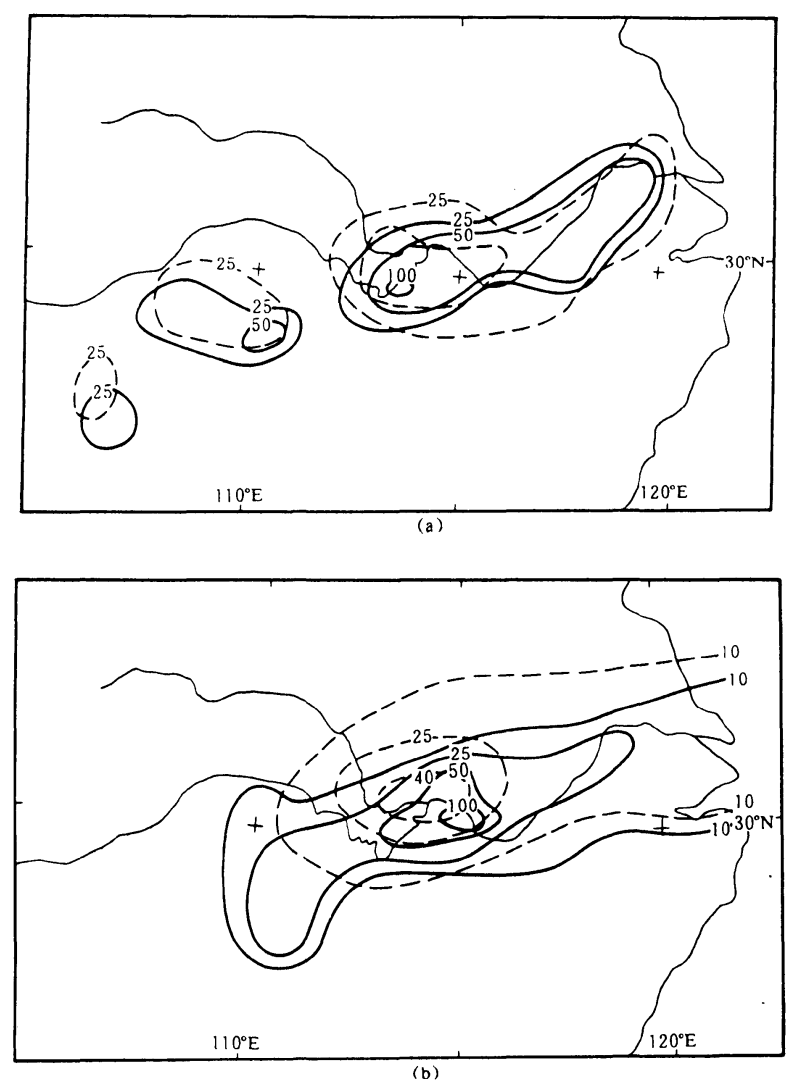

Fig. 17. Predicted (dashed lines) and observed (solid lines) of 24-hr precipitation patterns associated with a low-level shear line, (a) for 00 GMT, 2 July 10-00 GMT 3 July, 1987, and (b) for 12 GMT, 2 July 1987-12 GMT, 3 July 1987, Unit: $\mathrm{mm}$. (Zou, 1989).

ary layer, and topography. An effort toward these aspects has been made by $\mathrm{Xu}$ and Ding (1990) that have improved the cumulus parameterization scheme in the Wuhan limited-area precipitation 
model. It is observed that cumulus and stratiform clouds often coexist in a rain-bearing synoptic system during the Meiyu season, and the associated precipitation amount may be amplified by their interaction. With some important processes of cloud physics taken into account, a simple seeder-feeder model to describe this process of interaction within the framework of a Kuo-type cumulus parameterization is suggested. This scheme was applied to six experiments of prediction of precipitation during the Meiyu period using of the Wuhan limited-area precipitation model. The results are very encouraging, especially for cases of coexistence of cumulus and stratiform clouds. The predicted rainfall amount was increased to $30-40 \%$ of the total rainfall amount, mainly caused by ice crystal effects and to a lesser extent by collision effects.

\section{Concluding remarks}

China is situated in a monsoon-affected area. Each year during spring and summer the summer monsoon brings in large quantities of moisture, which is a prerequisite for triggering off summer monsoon rainfalls in China. Following the northward advance of the summer monsoon, the major monsoon rain belt also shifts northward, but in a stepwise manner. This unique feature of movement of the rain belt may be closely related to the effects of the Tibetan Plateau and the sudden change in the general circulation in East Asia. Therefore, three major rainy seasons (the pre-summer rainy season in South China, the Meiyu season and the rainy season in North China), which are a manifestation of the northward advance of the rain belt, are a result of a strong interaction of the summer monsoon and the unique East Asian large-scale terrain features. Against the background of this large-scale interaction, the monsoonal low-frequency modes, especially the 30-50 day oscillation, further modulate the intraseasonal variability of summer monsoon rainfalls.

The summer monsoon rainfall in China shows evident spatial and temporal inhomogeneity. They are specially characterized by long persistence and great severity. This often leads to extensive and excessively heavy rainfalls. Many observational studies have documented that the low-level jet and subsynoptic scale or meso-scale rain-bearing systems make major contributions to development and maintenance of these heavy rainfall events. However, the development of low-level jets and meso-scale systems (mainly meso- $\alpha$ scale) is in turn associated with the large-scale topography, especially the Tibetan Plateau, and variability in the monsoonal airflow.

The summer monsoon rainfalls in China are not of regional significance, but also may exert a planetaryscale effect through their rainfall-created heating fields. This effect may be felt at rather extensive longitudinal and meridional ranges, inducing thermally-driven zonal and meridional circulation (Yeh and Gao, 1979).

Due to the above-mentioned unique conditions of the summer monsoon and the large-scale topography, some significant differences may be found between the summer rainfalls in China and United States, although they are situated in approximately the same latitudinal zone. For example, in contrast to the USA, tornadoes seldom occur in China, which is prone to rainstorms. On the other hand, the differences between the Meiyu in China and Baiu in Japan are also noted (Ninomiya and Murakami, 1987; Qian et al., 1991). The regional character of these summer rainfalls remain to be further studied in the future.

\section{Acknowledgments}

I wish to thank Mrs. Liu Lanzhi for typing the manuscript and Mrs. Zhang Wanpei for producing all the illustrations.

\section{References}

Anthes, R.A., 1990: Renent applications of the Penn State/NCAR mesoscale model to synoptic, mesoscale, and climate sutdies. Bull. Amer. Meteor. Soc., 71, 1610-1629.

Cao, S.-Y., 1990: The observations of the Huanghai Bohai and the Sea of Japan highs and the heavy rain in North China in summer. Quart. J. Appl. Meteor., 1, 162-168 (in Chinese).

Chen, G.T.J. and C.-P. Chang, 1980: The structure and vorticity budget of an early summer monsoon trough ("Mei-Yu") over southeastern China and Japan. Mon. Wea. Rev., 108, 942-953.

Chen, L.-X. and W.-L. Li, 1985: The atmospheric heat budget in summer over Asia monsoon area. Advances in Atmos. Sci., 2, 487-498.

Chen, L.-X, S.-H. Luo and R.-G. Shen, 1984: The Asian summer monsoon and its ralation to the rainfall in China. Advances in Atmos. Sci., 2, 263-276.

Chen, Q., 1982: The instability of the gravity-inertia wave and its relation to low-level jet and heavy rainfall. J. Meteor. Soc. Japan, 60, 1041-1057.

Chen, S.-J., 1989: The vertical coupling of upper and lower jets in an heavy rainfall case during the late period of Meiyu period-Numerical experiment. Acta Meteorologica Sinica. 47, 8-16 (in Chinese with English abstract).

Chen, S.-J. and L. Dell'Osso, 1984: Numerical prediction of the heavy rainfall vortex over Eastern Asia monsoon region. J. Meteor. Soc. Japan, 62, 730747.

Chou, L.C., C.-P. Chang and R.T. Willams, 1990: A numerical simulation of the Meiyu front and the associated low level jet. Mon. Wea. Rev., 118, 1408-1428.

Ding, Y.-H., Z.-Y. Cal and J.-S. Li, 1978: A study on the excessively heavy rainfall in Henan province early in August 1975. Scientia Atomspherica Sinica, 2, 276289 (in Chinese with English abstract). 
Ding, Y.-H., J.-S. Li, Z.-Y. Cai, S.-X. Zhao and S.-Y. Tao, 1980: An analysis of some kinds of synoptic scale systems affecting the heavy rains in North China in summer. Collected Papers No. 9 of Institute of Atmospheric Physics (IAP): Rainstorms and Severe Convective Weathers. 1-13 (in Chinese).

Ding, Y.-H., H.-Z. Li, Z.-Y. Cai and J.-S. Li, 1980: On the physical conditions of occurrence of heavy rainfall and severe convective weather. Eighth Conference on Weather Forecasting and Analysis, June 10-13, 1980, Dever, Colo. AMS, Boston, Mass.

Ding, Y.-H. and E.R. Reiter, 1982: A relationship between planetary waves and persistent rain and thunderstorms in China. Arch. Met. Geoph. Bioki., Ser. $B, \mathbf{3 1}, 221-252$.

Ding, Y.-H. and J. Hu, 1988: The variaiton of the heat sources in East Asia in the Early summer of 1984 and their effects on the large-scale circulation in East Asia. Advances in Atmos. Sci., 6, 171-180.

Ding, Y.-H. and X.-J. Zhou, 1988: And overview of the national research program of the monitoring system and the very short range prediction of the disastrous weather in China. Annual Report, 1987-1988, Academy of Meteorological Science, State Meteorological Administration, 1988, 63 pp.

Ding, Y.-H. and X.-F. Wang, 1988: An analysis of distribution of apparent heat sources and sinks over the middle reaches of Yangtze River during the Meiyu season in 1983. Tropical Meteorology, 4, 134-145 (in Chinese).

Duan, T.-Y., 1983: An analysis of the atmospheric heat source and the energy budget over.the South China Sea in summer 1979. Proc. the Symposium on the Summer Monsoon in South and East Asia, 15-21 August, 1980. Hangzhou, China, Yunnan People's Press, 102-115 (in Chinese with English abstract).

Guo, Q.-Y. and J.-Q. Wan, 1981: The distribution of precipitation in China during the summer monsoon period for recent 30 years. Acta Geographica Sinica, 36, 187-195 (in Chinese).

Guo, X.-R., Z.-H. Yan and G.-A. Zhong, 1990: BMC limited area model: operational application and research. East Asia and Western Pacific Meteorology and Climate, World Scientific, 572 pp.

Huang, A.-L. and K. Gao, 1982, A dynamic analysis of coupling effect of upper-level jet and low-level jet. $J$. University of Hangzhou, 9, 356-364 (in Chinese).

Huang, A.-L., K. Gao and Y.-F. Li, 1987: A preliminary simulation of a heavy rain process during Meiyu season. Acta Meteorologica Sinica, 45, 426-436 (in Chinese).

Huang, S.-S., 1986: The presummer Heavy Rainfall over South China, Guangdong Science and Technology Press, 243 pp.

Jiang, J.-X., H.-M. Ye and M.-Z. Chen, 1990: Investigation of meso-scale convective cloud cluster in South China. Quart. J. Appl. Meteor., 1, 232-241 (in Chinese).

Jin, Z.-H., 1982: A study of the meso-scale system of heavy rainfall over valleys of the Changjiang-Huaihe Rivers. Scientia Atmospherica Sinica, 6, 187-194 (in Chinese).
Ju, J.-H. and H.-B. Luo, 1987: The structures of the atmospheric heat sources and the relationship between the heat sources and the tropical circulation in the formation of the summer monsoon in East Asia. Collected Papers in Meteorological Science and Technology, No. 10 (Monsoon Meteorology), China Meteorological Press, 235 pp (in Chinese).

Kato, K., 1985: On the abrupt change in the structure of Baiu front over the China continent in late May of 1979. J. Meteor. Soc. Japan, 63, 20-35.

Kato, K., 1987: Airmass transformation over the semiarid region around North China and abrupt change in the structure of the Baiu front in early summer. J. Meteor. Soc. Japan, 65, 737-750.

Kato, K., 1989: Seasonal transition of the low-level circulation systems around the Baiu front in China in 1979 and its relation to the Northern summer monsoon. J. Meteor. Soc. Japan, 67, 205-219.

Kuo, Y.-H., L. Cheng and J.-W. Bao, 1988: Numerical simulation of the 1981 Sichuan flood catastrophe. Part I: Evolution of a mesoscale southwest vortex. Mon. Wea. Rev., 116, 2481-2504.

Lau, K.-M., G.-J. Yang and S.-H. Shen, 1988: Seasonal and intraseasonal climatology of summer monsoon rainfall over East Asia. Mon. Wea. Rev., 116, 1837.

Li, M.-C., 1980: The relationship between the presummer excessively heavy rainfall in South China and ageostrophic wind of low-level jet. Collected Papers of Institute of Atmospheric Physics, No. 9, Science Press (in Chinese).

Li, Y.-F., A. Huang and K. Gao, 1987: The role of convective heating in heavy rain system during Mei-rains season. Scientia Sinica (Series B), 182-197 (in Chinese with English abstract).

Li, Z.-G., L.-Y. Deng and H.-S. Xue, 1988: A composite analysis on widespread torrential rainfall during first rainy season in South China J. Tropical Meteorology, 4, 97-106.

Liang, B.-Q. and C.-L. Bao, 1980: The mesoscale analysis of the presummer rainstorms over South China. Selected Papers on Rainstorms, Jilin People's Press. 259 pp (in Chinese).

Liang, P.-D., 1987: The developing process of monsoon in eastern China and the change of stratification in the atmosphere. Weather in North China. Beijing University Press, 74-84 (in Chinese).

Liang, P.-D., 1988: Indian summer monsoon and rainfall in North China in summer, Acta Meteorologica Sinica, 46, 75-41 (in Chinese).

Lin, C.-Y., J,-Z. Lu and G.-Y. Xu, 1983: A tentative study on the characteristics of the summer monsoon activity over the middle and lower Yangtze River. Proc. the Symposium on the Summer Monsoon in South and East Asia, 15-21 August, 1980, Hangzhou, China, 254 pp. Yunnan People's Press (in Chinese).

Lin, Z.-Q., 1987: The continual research of the movement of summer monsoon rain belt in eastern part of China. Collected Papers of Meteorological Science and Technology, No. 10 (Monsoon Meteorology), China Meteorological Press, 235 pp (in Chinese). 
Lu, H.-C. and J.-W. Wang, 1988: The feature and stability of meso-scale disturbance in the Meiyu front. Scientia Atmospherica Sinica, 12, 182-190 (in Chinese with English abstract).

Luo, H.B. and M. Yanai, 1984: The large-scale circulation and heat sources over the Tibetan Plateau and surrounding areas during the early summer of 1979. Part II: Heat and moisture budgets. Mon. Wea. Rev., 112, 966-986.

Madden, R. and P. Julian, 1972: Description of global scale circulation in the tropics with a 40-50 day period. J. Atmos. Sci., 29, 1109-1123.

Matsumoto, J., 1989: Heavy rainfalls over East Asia, International J. Climato., 9, 407-423.

Matsumoto, S. and K. Ninomiya, 1971: On the mesoscale and medium-scale structure of a cold front and the relevant vertical circulation. J. Meteor. Soc. Japan, 49, 648-662.

Ninomiya, K. and T. Akiyama, 1974: Band structure of meso-scale echo cluster associated with low-level jet stream. J. Meteor. Soc. Japan, 52, 300-313.

Ninomiya, K. and H. Muraki, 1986: Large-scale circulations over East Asia during Baiu period of 1979. J. Meteor. Soc. Japan, 64, 409-429.

Ninomiya, K. and T. Muraki, 1987: The early summer rainy season (Baiu) over Japan. In Chapter 4, Monsoon Meteorology, Oxford University Press, New York. 93-121.

Ninomiya, K., 1989: Cloud distribution over East Asia during Baiu period of 1979. J. Meteor. Soc. Japan, 67, 639-658.

Qian, Z.-A., R.A. Bromley and M.A. Agles, 1991: Some analyses and numerical simulations of Meiyu in East Asia in 1983. Advances in Atmos. Sci., 8, 67-78.

Qiao, Q.-M., L. Zhang, Y.-Y. Tao and X. Zhang, 1986a: The compositing analysis of cloudiness and precipitation during the Meiyu rainstorms. Proc. the Mesoscale Weather Experiment in East China, Vol. III, 19-25 (in Chinese).

Qiao, Q.-M., L. Zhang, X. Zhang and B. Deng, 1986b: Large-scale compositing analysis and model of the Meiyu in China. Part II. Proc. the Meso-scale Weather Experiment in East China, Vol. III, 11-18 (in Chinese).

Qiu, B.-H. and Y.-H. Ding, 1979: The circulation structure during the Meiyu period of 1973. The Formation and Prediction of Precipitaton During The Meiyu in Summer. Science Press. 23-32 (in Chinese).

Rong, G.-X., Y.-T. Wang, H. Peng and K.-X. Xue, 1987: On the major monsoon weather systems in the South China. Collected Papers on Meterorlogical Science and Technology, No. 10 (Monsoon Meteorology), China Meteorological Press, 235 pp (in Chinese).

Shi, S.-W. and J.-M. Chao, 1983: The summer monsoon in North China. Proc. Symposium on the Summer Monsoon in South and East Asia, 10-5 October 1982, Kunming, China, Yunnan People's Press, 7285 (in Chinese).

Si, G.-W., 1976: A numerical analysis of dynamic factors leading to genesis and develoment of a ChangjiangHuaihe River cyclone. Scientia Atmospherica Sinica,
2, 6-17 (in Chinese)

Si, G.-W., Z.-X. Yu, R.-R. Li and J.-Z. Yan, 1982: A case analysis on the formation of low-level jet stream associated with "Baiu front". Scientia Atmospherica Sinica, 6. 165-170 (in Chinese).

Si, G.-W., 1988: The Heavy Rainfall and Severe Convective Circulation Systems. China Meterologica Press. $350 \mathrm{pp}$.

Si, G.-W., 1989: On the large-scale circulation of Meiyu system over East Asia. Acta Meterorlogica Sinica, 47, 312-323 (in Chinese).

Sun, S.-Q. 1986: The background field of large-scale lowlevel jet in East Asia and the cross-equatorial airflow in the Eastern Hemisphere. Acta Meteorologica Sinica, 44, 55-62 (in Chinese).

Sun, S.-Q., 1990: The activity of large-amplitude gravity wave in the Meiyu front and its relationship to the environmental field. Scientia Atmospherica Sinica, 14, 163-172 (in Chinese).

Takahashi, H., 1989: Fromation of a rain belt and the structure of the front during the Baiu season on the Chinese continent. Geographycal Rev. of Japan, 62A, 853-876 (in Japanese with English abstract).

Tao, S.-Y. and Y.-H. Ding, 1981: Observational evidence of the influence of the Qinghai-Xizang (Tibet) plateau on the occurrence of heavy rain and severe convective storms on China. Bull. Amer. Meteor. Soc., 61, 23-30.

Tao, S.-Y., Y.-H. Ding, S.-Q. Sun, A.-Y. Cai, M.-D. Zhang, Z.-Y. Fang, M.-T. Li, X.-P. Zhou, S.X. Zhao, S.-T. Dian, Y.-L. Li, Q.-J. Zhu and Q.-Y. Zhang, 1980: Severe Rainstorms in China. Science Press, 225 pp (in Chinese).

Tsay, C.Y. and G.T.J. Chen, 1981: Dynamic processes for vertical motion in a Meiyu system. Pap. Meteor. Res., 3, 67-77.

Uccellini, L. and D.R. Johnson, 1979: The coupling of upper and lower tropospheric jet streak and implications for the development of severe convective storms. Mon. Wea. Rev., 107, 682-703.

Wang, J.-Z. and M.-C. Li, 1982: Cross-equatorial flow from Australia and monsoon over China. Scientia Atmospherica Sinica. 6, 1-10 (in Chinese with English abstract).

Wu, T.-Y., 1990: A review of the Taiwan Area Mesoscale Experiment (TAMEX) and post-field phase activities. Pro. Workshop on TAMEX Scientific Results. 24-26 September, 1990, Boulder, NSF, NSC, NCAR, $1-6$.

Xiao, W.-J. and Q.-S. Chen, 1984: Case studies of relationship between upper level and low-level jets and reinstorms. Scientia Atmospherica Sinica, 8, 83-88.

Xie, Y.-B., 1956: A study of analysis of rain-producing synoptic systems in summer half year in China. Acta Meteorologica Sinica, 27, 1-24 (in Chinese).

Xie, Y.-B., 1984: Observational and theoretical studies of the moist baroclinic atmosphere. Advances in Atmos. Sci., 1, 141-149.

$\mathrm{Xu}, \mathrm{X} .-\mathrm{H}$. and Y.-H. Ding, 1990: A cumulus parameterization scheme with consideration of interaction of stratiform clouds and cumulus and its application to precipitation numerical prediction. Scientia Sinica (Series B), 998-1008. 
Yeh, D.-Z. and Y.X. Gao, 1979: Meteorology of QinghaiXizhang (Tibet) Plateau. Science Press 228 pp (in Chinese with English abstract).

Yeh, T.-C., S.-Y. Tao and M.-C. Li, 1958: The abrupt phenomena of the general atmospheric circulation in June and October. Acta Meteorologica Sinica, 29, 246-263 (in Chinese).

Yoshino, M.M., 1965: Four stages of the rainy season in early summer Over East Asia (Part I), J. Meteor. Soc. Japan, 43, 231-245.

Yoshino, M.M., 1971: Water Balance of Monsoon Asia, University of Hawaii Press, Honolulu and University of Tokyo Press, Tokyo. 308 pp.

Zhang, B.-C., 1990: A Study of the Meiyu Rainstorms over the Yangtze Valley. China Meteorological Press. 269 pp (in Chinese).

Zhang, K.-S., 1988: On mesoscale instability of a baroclinic flow, I: Symmetric instability. Acta Meteorologica Sinica, 46, 258-266.

Zhang, L., Q.-M. Qiao, B. Deng and X. Zhang, 1986: Large-scale compositing analysis and model of the Meiyu (Bailu) front. Scientia Atmospherica Sinica, Special Issue, 191-201.

Zhang, M.-L. and W.-L. Li, 1979: Case studies of the Meiyu rainstorms. Formation and Prediction of Precipitation during Meiyu Season. Collected Paper of IAP, No. 7, Science Press, 109 pp (in Chinese).

Zhao, S.-X. and X.-P. Zhou, K.-S. Zhang and S.-H. Liu,
1982: Numerical simulation experiment of the formation and maintenance of meso-scale low. Scientia Atomlpherica Sinica, 6, 109-117 (in Chinese with English abstract).

Zhao, S.-X., 1988: Energetics of cyclogenesis on Meiyu front. Scientia Atmospherica Sinica, Special Issue, 191-201.

Zhong, R.-G. and B.-Q. Liang, 1984: The low-level jet stream over South China and its effect on heavy rainfall. Proc. Symposium on Tropical Circulation and System, Ocean Press.

Zhou, X.-P. and X.-F. Hu, 1983: A brief analysis and numerical simulation of the Sichuan extraordinarily heavy rainfall event. Proc. the First Sino-American Workshop on Mountain Meteorology, Science Press, Beijing, $697 \mathrm{pp}$.

Zhou, X.-P., S.-X. Zhao and B.-Y. Zhang, 1984: A numerical simulation of the meso-low formation on Meiyu front. Scientia Atmospherica Sinica, 8, 353361 (in Chinese).

Zhu, K.-Z., 1934: Monsoon in Southeast Asia and rainfall amount in China. Acta Geographica Sinica, 1, 1-27 (in Chinese).

Zou, J.-M., 1989: The monitoring and prediction of rainstorms and severe convective weather systems in China. Mesoscale Forecasting and Its Application. WMO No. 712, 1989, 49-86.

\title{
中国における夏のモンスーン季の降雨
}

\author{
Ding Y.-H.
}

(国家気象局中国気像科学研究院)

\footnotetext{
本論文では、東アジアにおけるモンスーン循環と大規模な地域特性を中心に、中国における夏のモンスー ン季の降雨に関する包括的なレビューを行なった。示される内容は、中国における夏のモンスーン季の降 雨の気候学、華南における初夏の雨・梅雨・華北の雨季を含めた夏のモンスーン季の降雨の地域特性、夏 のモンスーン季の降雨に伴う下層ジェット、夏のモンスーン季における降雨システムの中規模スケールで の特徵、大気の熱源とその東アジアにおける大気大循環の変化への影響、中国における夏のモンスーン季 の降水に関する数値実験及び数值予報、である。
} 